
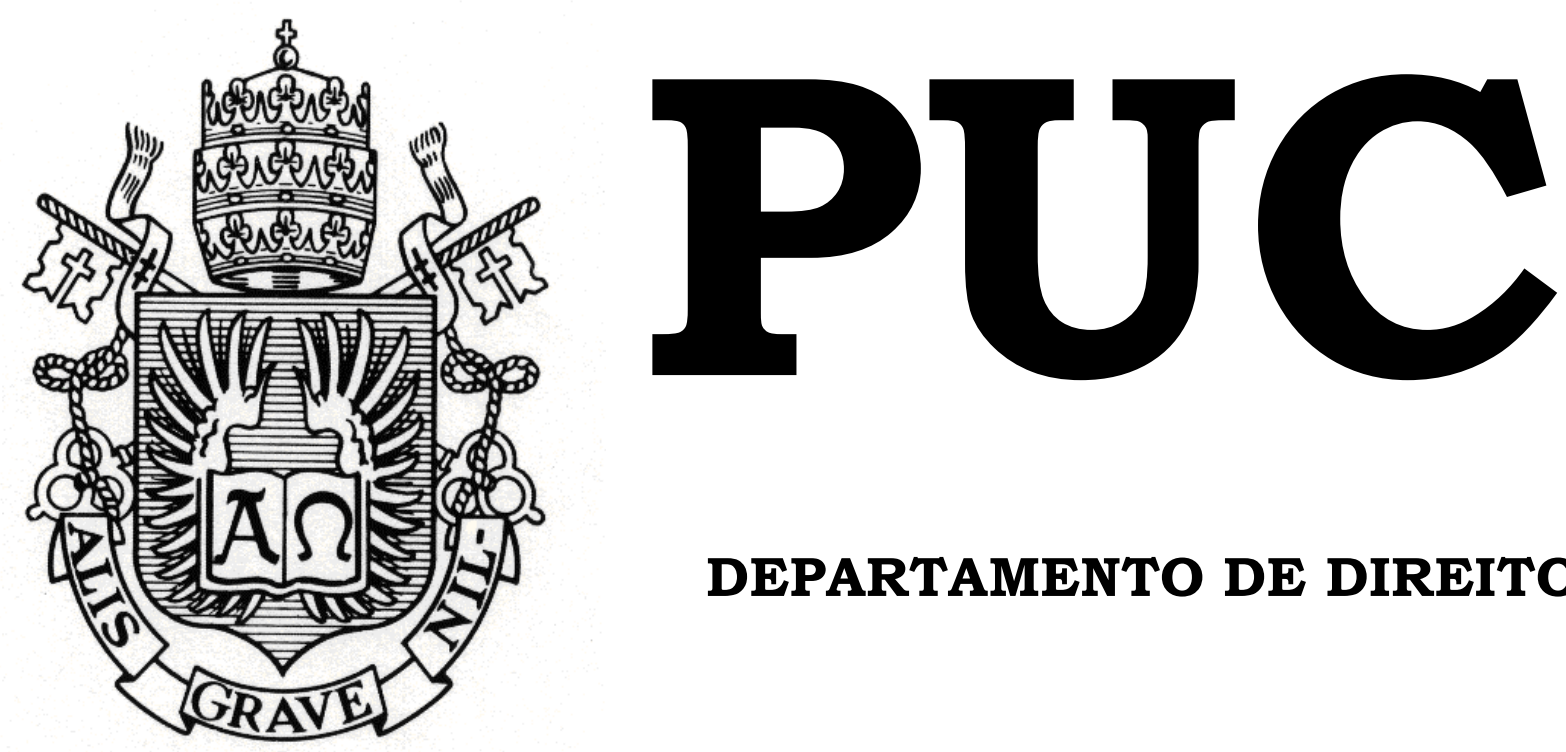

DEPARTAMENTO DE DIREITO

DIREITO, ARTE e Eficácia Social da Norma

por

Juliana Mansur

ORIENTADOR: Rosângela Lunardelli Cavallazzi

2014.2

PONTIFÍCIA UNIVERSIDADE CATÓLICA DO RIO DE JANEIRO

RUA MARQUÊS DE SÃO VICENTE, 225 - CEP 22453-900

RIO DE JANEIRO - BRASIL 


\section{DIREITO, ARTE e Eficácia Social da Norma}

$$
\text { por }
$$

Juliana Mansur

Monografia apresentada ao

Departamento de Direito da

Pontificia Universidade Católica do

Rio de Janeiro (PUC-Rio) para a obtenção do Título de Bacharel em Direito.

Orientador(a): Rosângela Lunardelli Cavallazzi 


\section{DEDICATÓRIA}

Em especial ao meu pai, que me inspira a cada dia por ser quem é, além de sempre me apoiar e incentivar a concluir e me dedicar ao que faço.

A minha mãe, por ter me feito respirar arte ao longo da minha vida e por toda sensibilidade, carinho e apoio nas decisões tomadas.

A minha irmã, por sempre estar do meu lado, me apoiando e dando força as minhas escolhas.

Aos amigos que estiveram ao meu lado ao longo dessa jornada compartilhando risadas, material de estudo e muito conhecimento, além de me ajudar a manter a calma todas as vezes que alguma dúvida surgia.

Ao grupo de pesquisa LADU, do qual com muito orgulho faço parte. Cada pesquisador que vejo a dedicação para alcançar seus objetivos sendo fonte de admiração e em especial para a Coordenadora dele e minha orientadora, Rosângela Cavallazzi, que acreditou no tema e não me deixou desistir por nem um instante.

Agradeço por cada segundo que vocês estiveram ao meu lado me dando forças, direta ou indiretamente, para que o caminho pudesse ser percorrido por completo. Sem vocês nada disso seria possível. 


\section{Resumo}

Este trabalho se propõe a analisar, sob a perspectiva do direito à cidade novas dimensões de eficácia social da norma urbanística através da retroalimentação entre Direito e Arte. Pretendemos demonstrar o papel fundamental da Arte no processo de conscientização e exercício dos direitos sociais que constituem o direito à cidade na proteção do direito dos vulneráveis.

\section{Palavras chaves}

Direito à Cidade; Arte; Direito; Eficácia Social da Norma; Vulnerabilidade; Função Social da cidade; Paisagem Urbana. 


\section{Sumário}

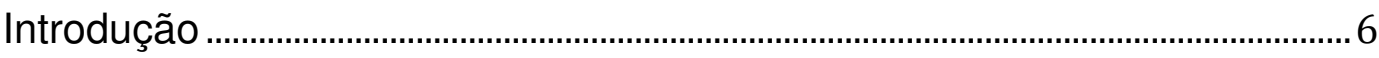

1. Contextualizando o Direito à Cidade .......................................................................

1.1 Desafios da cidade contemporânea e conflitos urbanos................................

1.2. Possibilidades no campo jurídico ..................................................................... 13

1.2.1. Função social da propriedade pública e privada e instrumentos jurídico-urbanísticos na perspectiva das funções sociais da cidade............ 13 1.2.2. Direito Urbanístico brasileiro e Direito à Cidade: o microssistema do Estatuto da Cidade 18

1.2.3. Vulnerabilidades e o feixe de direitos sociais que compõem o Direito à Cidade. 20

2. Conexão entre Arte e Direito e seu efeito potencializador da tutela de

Direitos 22

2.1. Teatro 26

2.2. Cinema 31

2.3. Arte Urbana. 37

3. Paisagem em Movimento. 41

3.1. Conexões na tutela jurídica: do Decreto lei $n^{0} 25$, de 30 de novembro de 1937 sobre Tombamento à proteção da paisagem urbana na perspectiva da eficácia social da norma urbanística 43

3.2. Arte e direito na paisagem urbana: Arte no processo de conscientização e exercício dos direitos sociais que constituem o direito à cidade. 58

4. Conclusão 62

5. Bibliografia 65 


\section{Abreviações}

ART.

IPHAN

artístico nacional

MP
Artigo

Instituto do patrimônio histórico e

Ministério Público 


\section{Introdução}

Este trabalho pretende abordar o acesso ao direito à cidade e ao feixe de direitos que dele decorrem a partir do estudo da arte política na cidade, no intuito de verificar como tais manifestações contribuem para a eficácia social da norma urbanística.

Verificamos vários desafios na cidade contemporânea que revelam e agravam situações de vulnerabilidade, tornando perceptíveis conflitos urbanos imprevisíveis, comprometendo a qualidade do espaço, das relações humanas e da vida das pessoas.

O campo do Direito brasileiro apesar de estar, em regra, pautado por paradigmas modernos e insuficientes para o enfrentamento das questões urbanas contemporâneas, tem encontrado novas possibilidades na área dos interesses e direitos difusos, especialmente no Direito Urbanístico.

Propomos o estudo relacionado entre Arte e Direito visando potencializar o Direito Urbanístico no enfrentamento dos conflitos urbanos. Consideramos que a correlação entre Arte e Direito pode gerar processos na transformação do Direito, no sentido da eficácia social da norma urbanística. Entendemos que a busca pela exequibilidade de normas urbanísticas que viabilizam as funções sociais da cidade pode ampliar a proteção dos direitos sociais que compõem o direito à cidade visando a tutela dos vulneráveis.

O próprio campo jurídico deveria estimular a ocupação de espaços por manifestações artísticas que despertem a consciência coletiva, explorando a riqueza do humanismo jurídico que não está limitado pela formalidade da área jurídica, mas dialoga com todas as outras áreas conhecidas. Consideradas potenciais transmissoras de conhecimento jurídico pertinente a cada região e necessidade de cada grupo social, essas artes teriam a capacidade de dar indícios acerca do direito a ser tutelado e buscar possíveis soluções e caminhos para que os mesmos se tornem 
eficazes e exequíveis como a norma prevê que sejam em seu texto. Para a eficácia dessa relação, devem haver porta-vozes e representantes reais de um núcleo e setor em cada área.

A Constituição brasileira de 1988, considerada constituição cidadã, constitui, sem dúvida, o reconhecimento dos direitos sociais e da sua necessária efetividade. Considerada democrática, tem a possibilidade de se transformar diante de cada realidade social, pois não se trata apenas de um instrumento de ordem, mas de progresso, evolução e bem-estar social. Esta, para que seja totalmente eficaz, deve-se manter conectada a cada caso concreto libertando-se de um necessário e contínuo formalismo na aplicabilidade de normas, em prol de uma interpretação do real, para que os direitos fundamentais e principais direitos humanos possam ser respeitados ao exigir a aplicação da legislação necessária.

O trabalho está estruturado em três capítulos. No primeiro capítulo, contextualizamos os desafios das cidade brasileiras contemporâneas a partir da função social da propriedade pública e privada, ressaltando o importante papel do Estatuto da Cidade e do Direito à cidade na expectativa da identificação das vulnerabilidades e de possíveis respostas no campo jurídico.

O segundo capítulo busca estabelecer conexão entre Arte e Direito e apresentar seus efeitos potencializadores em prol da exequibilidade dos direitos sociais. A abordagem explicita três formas de manifestações artísticas presentes na cidade -Teatro, Cinema e Arte Urbana- a partir de três casos referência. $\mathrm{Na}$ cidade, o efeito gnoseológico da Arte, muito trabalhado por Marx, pode produzir um efeito revolucionário em todos os setores da vida cultural e contribuir para um estilo mais dinâmico, mais livre da influência de formas e tipos tradicionais; para que esta possa exercer seu poder de influência do melhor modo; criando reais caminhos para exequibilidade e eficácia do Direito. 
De acordo com os exemplos na história da arte, como mostra Leandro Konder em Os Marxistas e a Arte ${ }^{1}$, influência de diversas obras de arte se mostram profundas e duradouras no entendimento do real. A forma como a Arte pode alterar sensivelmente a prática jurídica é de extrema relevância e importância para o estudo.

O último capítulo busca relacionar arte e direito na paisagem urbana para identificar a tutela jurídica da conquista de direitos, especialmente sobre a paisagem urbana. Prioriza a tutela jurídica para a proteção da paisagem urbana mediante a eficácia social da norma urbanística, considerando a arte no processo de conscientização e exercício dos direitos sociais que constituem o direito à cidade.

\footnotetext{
${ }^{1}$ Konder, Leandro. Os Marxistas e a Arte. p. 22.
} 


\section{Contextualizando o Direito à Cidade}

\subsection{Desafios da cidade contemporânea e conflitos urbanos}

A cidade contemporânea passa por um momento importante. De um lado grita-se pelos direitos humanos, e de outro, os direitos de propriedade privada e de lucro se sobrepõem a todas as outras noções de direitos em que se possa pensar. ${ }^{2}$

Identifica-se vários desafios da cidade contemporânea revelando cada vez mais conflitos urbanos imprevisíveis que agravam as vulnerabilidades de pessoas, espaços e relações. $\mathrm{O}$ atual cenário retrata diversas inconstitucionalidades que vem ocorrendo ao longo do território em diferentes proporções e circunstâncias. Devemos observar as cidades sob uma perspectiva integradora, não segregadora, à luz dos direitos humanos como direitos coletivos.

Robert Park, ao definir a cidade contemporânea, a apresenta como um mundo criado pelo homem, que faz com que o mesmo tenha que se recriar também para que este possa se adaptar ao mundo que está condenado a viver. Ao escolher a cidade que vamos morar, estamos decidindo muitos caminhos da nossa vida complexa; como nosso estilo de vida e tipos de relação que pretendemos criar com o mundo. ${ }^{3}$

Milton Santos define a cidade como um grande meio de produção material e imaterial, lugar de consumo, nó de comunicação. A economia política da cidade seria a forma como a cidade se organiza em face da produção e como os diversos atores da vida urbana encontram seu lugar, em cada momento, dentro da cidade. A vida urbana induz à criação de meios coletivos. ${ }^{4}$ Através de meios coletivos, torna-se mais fácil que sejam

\footnotetext{
${ }^{2}$ HARVEY, David. Cidades Rebeldes- $o$ direito à cidade pp.28-30

${ }^{3}$ Ibid. pp. $20-40$

${ }^{4}$ SANTOS, Milton. Por uma Economia Política da Cidade. p. 114
} 
enxergadas e propostas novas formas de solução e busca pela eficácia dos direitos sociais dentro de cada realidade.

Zygmunt Bauman, ao afirmar que $A$ liberdade individual deve ser defendida e garantida coletivamente. ${ }^{5}$ reforça a importância da proteção dos direitos coletivos, na medida que protegendo o direito do todo, pelo todo, há uma maior eficácia na proteção do particular. Esse sentido não constitui novidade, Aristóteles já afirmava: "Uma cidade deve ser construída de modo a proporcionar a seus habitantes segurança e felicidade."6

A Constituição Federal de 1988 tem implícito, ao longo de seu texto constitucional, forte caráter democrático e consagra o exercício da cidadania através das cidades, como meio de possibilitar a concretização do objetivo fundamental da República Federativa do Brasil de construir uma sociedade livre, justa e solidária.

Neste nosso trabalho pretendemos enfrentar alguns desafios da cidade contemporânea com seus conflitos na perspectiva da efetividade dos direitos sociais que compõem o direito à cidade.

Neste sentido compreendemos direito à cidade segundo vários conceitos complementares.

\section{A Carta Mundial pelo Direito à Cidade, com seu conceito}

formulado por entidades participantes do I Fórum Social Mundial em 2001, bem expressa essa noção:

"O Direito à Cidade é interligado e interdependente a todos os direitos humanos internacionalmente reconhecidos, concebidos integralmente. Inclui, portanto, os direitos à terra, aos meios de subsistência, ao trabalho, à saúde, à educação, à cultura, à moradia, à proteção social, à segurança, ao meio ambiente sadio, ao saneamento, ao transporte público, ao lazer e à informação. Inclui também (...) a garantia da preservação da herança histórica e cultural." ${ }^{7}$.

Rosângela Lunardelli Cavallazzi considera :

\footnotetext{
${ }^{5}$ BAUMAN, Zygmunt. Em busca da política. p. 15

${ }^{6}$ CHOAY, Françoise. O Urbanismo. Editora Perspectiva S.A 2000 p. 206

${ }^{7}$ I Fórum Social Mundial em 2001. Porto Alegre
} 
A cidade contemporânea carece de relações de confiança. Esta relação de confiança implica na composição cotidiana das condições de dignidade (moradia, saúde, trabalho) ${ }^{8}$, entrelaçada com as condições da liberdade (educação, serviços públicos -implícito o saneamento-, ao lazer, à segurança), e com as condições de confiança no futuro (preservação do patrimônio cultural, histórico e paisagístico, ao meio ambiente natural e construído equilibrado -implícita a garantia do direito a cidades sustentáveis. ${ }^{9}$

Esses dois conceitos tratam os direitos humanos e sociais como básicos e fundamentais para os indivíduos, garantindo-os a partir do direito à cidade, que deve proporcionar acesso a todos eles, e garantir a eficácia dos direitos através da real aplicabilidade dos mesmos tutelando, assim, os vulneráveis.

LEFEBVRE também foi considerado, especialmente quando propõe a cidade como valor de uso:

"Se se deseja superar o mercado, a lei do valor de troca, o dinheiro e o lucro, não será necessário definir o lugar dessa possibilidade: a sociedade urbana, a cidade como valor de uso" 10

Com esta compreensão, o autor permite que possamos interpretar o direito à cidade para além da dimensão do mercado predominando assim a cidade como valor de uso. $\mathrm{O}$ valor de uso e troca, segundo Marx ${ }^{11}$, faz com que se perca o caráter social da atividade, pois a interferência humana na formação dos mesmos, torna-se alheia aos núcleos sociais que deveriam representa-los. Ao ser absorvido pelo mundo atual, o valor de uso acaba distanciando da realidade e do processo que a faz surgir.

$\mathrm{O}$ direito à cidade segundo David Harvey, não é uma forma de acesso individual ou em conjunto aos recursos que a cidade incorpora, mas

\footnotetext{
8 Esta classificação não indica qualquer hierarquia entre os diversos direitos sociais e fundamentais que compõem o direito à cidade (o conceito de direito à cidade, compreendendo o direito humano, difuso, núcleo de um sistema composto por um feixe de direitos incluindo o direito à moradia (implícita a regularização fundiária), à educação, ao trabalho, à saúde, aos serviços públicos (implícito o saneamento), ao lazer, à segurança, ao transporte público, a preservação do patrimônio cultural, histórico e paisagístico, ao meio ambiente natural e construído equilibrado (implícita a garantia do direito a cidades sustentáveis)

${ }^{9}$ Cavallazzi, Rosangela. 2013

${ }^{10}$ LEFEBVRE, Henri. $O$ direito à cidade. 3 ed. São Paulo: Centauro Editora, 2004b p. 74

${ }^{11}$ MARX, Karl. São Paulo. 1985. p. 84
} 
um direito de mudar e reinventar a cidade a partir das nossas vontades para que satisfaçam as necessidades humanas. Harvey ressalta, ainda, a forma como fomos feitos e refeitos ao longo da nossa história por um processo urbano impulsionado por forças sociais poderosas. Sustenta também o autor que todos devemos ter os mesmos direitos de construir os diferentes tipos de cidade que queremos que existam, direito de transformar a cidade em algo radicalmente diferente. ${ }^{12}$

Há uma busca constante para que as cidades se libertem do que vem acontecendo nos últimos tempos que acaba por arriscar a função agregadora e resolutiva das cidades. Estas se veem sendo modificadas e coordenadas pelo capital, antes mesmo que as pessoas possam assumir esse papel.

Harvey acredita que luta pelo direito à cidade está no centro da luta contra o capital. Em palestra inaugural do seminário "Lutas pela reforma urbana: o direito à cidade como alternativa ao neoliberalismo", organizado pelo Fórum Nacional de Reforma Urbana, realizada no Rio de Janeiro, ressalta que muitas das crises financeiras dos últimos 40 anos tiveram origem na urbanização. $O$ capitalismo produz excedente e aqueles que administram e recebem esse excedente decidem como e aonde vão reinvesti-lo. Ao investir em novas produções, são gerados novos empregos e uma ideia de melhoria de padrões de vida para o povo. Porém, o que realmente acontece é que o destino desse dinheiro acaba sendo o investimento em ativos financeiros e, principalmente, em propriedade imobiliária, tornando a cidade mais cara e inacessível a grande maioria que faz parte dela. A dinâmica observada apresenta um ciclo em que quanto mais é estimulada a construção imobiliária de luxo, maior é a quantidade de pobres expulsos de suas terras. Percebendo o direito à cidade dessas classes sendo claramente violado observamos, ainda, cada vez mais os ricos exercendo domínio sobre a cidade.

\footnotetext{
${ }^{12}$ Vide ideias desenvolvidas na conferência de David Harvey sobre Direito à Cidade no Rio de Janeiro em 29 de janeiro de 2014. <http://www.zorraquino.com.br/textos/referenciais/leia-apalestra-de-david-harvey-sobre-o-direito-a-cidade.pdf > Acesso em: 10/09/2009
} 
Podemos, então, pensar formas de urbanização diferentes que venham a garantir o direito à cidade tentando equacionar conflitos. Especialmente, os que antagonizam instituições financeiras e direitos sociais que integram o feixe de direitos que compõe o direito à cidade.

Para que esses direitos possam sem respeitados, devemos reconstruir as cidades através das demandas populares, de modo a atender as necessidades sociais e, de fato, exercer o nosso direito à cidade.

\subsection{Possibilidades no campo jurídico}

\subsubsection{Função social da propriedade pública e privada e instrumentos jurídico-urbanísticos na perspectiva das funções sociais da cidade}

Consideramos que a efetividade do direito à cidade pressupõe a efetividade da função social da propriedade pública e privada.

A função social, de acordo com a doutrina administrativista, abrange não só a propriedade privada. Maria Sylvia Zanella Di Pietro sustenta a plena aplicabilidade do princípio da função social às propriedades públicas, asseverando que "a destinação pública é inerente á própria natureza jurídica dos bens de uso comum do povo e de uso especial, porque eles estão afetados a fins de interesse público, seja por sua própria natureza, seja por destinação legal. ${ }^{13}$

Ao estender esse raciocínio aos bens dominicais, conclui a autora pela compatibilidade e aplicação do referido princípio para a propriedade pública.

O pressuposto da função social da propriedade à vinculação do Poder Público às normas urbanísticas é destacado na lição de José Afonso

\footnotetext{
${ }^{13}$ DI PIETRO. Maria Sylvia Zanella. Função Social da Propriedade Pública. Revista Eletrônica de Direito do Estado. Número 6 - abril/maio/junho. Salvador/Bahia. Disponível em http://www.direitodoestado.com/revista/REDE-6-ABRIL-2006-MARIA\%20SYLVIA.pdf. Acesso em $1^{\circ}$ de novembro de 2010.
} 
da Silva, o qual esclarece que o plano urbanístico se reveste de natureza pública:

"Por isso é que - na observação justa de Pedro Escribano Collato - a função social da propriedade privada urbana repousa em um pressuposto de primordial importância, qual seja: o de que a atividade urbanística constitui uma função pública da Administração, que, em conseqüência, ostenta o poder de determinar a ordenação urbanística das cidades, implicando nisso, a iniciativa privada e os direitos patrimoniais dos particulares." ${ }^{14}$

Portanto esse raciocínio pode ser transportado para a propriedade pública, eis que a ordenação urbana é caracterizada pela natureza pública de sua previsão. Por todo o exposto, tanto a propriedade privada quanto a pública se submetem ao ordenamento urbanístico, circunstância que autoriza o entendimento de que a propriedade pública urbana também deve atender a sua função social.

A Constituição Federal dedica um capítulo próprio para as disposições relativas à política urbana, orientada pela função social da propriedade e, em uma perspectiva maior, de toda a cidade. O texto constitucional deixa claro o objetivo de, através da subordinação da propriedade à função social, garantir o bem-estar de todos os habitantes, conforme prescrevem os arts. 182 e 183, corroborando também para matéria o disposto no art. $5^{\circ}$, XXIII, que erige o cumprimento da função social à envergadura de direito fundamental.

O Estatuto da Cidade estabelece diretrizes para aplicação dos arts. 182 e 183 da Constituição, reproduzindo a determinação em seu texto de que a propriedade se subordine ao cumprimento de sua função social. No âmbito infraconstitucional, além do microssistema do Estatuto da Cidade, a função social da propriedade também encontra guarida no art. $1.228, \S 1^{\circ}$, do Código Civil, que limita os direitos do proprietário que descumpre a função social, protegendo, do outro lado, os direitos do possuidor que confere função social à propriedade.

\footnotetext{
${ }^{14}$ SILVA, José Afonso da. Comentário contextual à Constituição. $4^{\mathrm{a}}$ ed. São Paulo: Malheiros, 2007
} 
Todo esse sistema normativo afasta o caráter absoluto do direito de propriedade:

"Não é mais admissível soerguer a vida empregando como apoio somente o indivíduo isolado. A vida não é uma Ilíada de um só. A complexidade do mundo moderno repele o pensamento autocrata (Cogito) que se obstina em aprisionar a existência em um elemento simples, desviado do espaço humano circundante. A unidade do singular só é conquistada através da progressiva associação com o mundo exterior, que se torna tão mais verdadeira e íntima quanto maior for o desapego à estabilidade particular e mais vasta a união com valores e princípios universalizáveis. (...)

A subjetividade, mais do que a confrontante auto-satisfação individual, desenvolve-se, antes, no sentido da reflexão, fruto de uma vontade dialogada e universalizável, produzida por um sujeito não apenas consagrado a si mesmo, mas que, na multiplicidade diferenciada dos seus interesses, descobre que sua própria emancipação depende, em ampla margem, da emancipação da pessoa humana." 15

Nosso trabalho privilegia o diálogo entre Arte e Direito no sentido de potencializar a garantia do direito à cidade. Portanto é importante registrar o marco normativo que encontramos na Constituição.

A Constituição, em seu art. 225, dispõe que todos têm direito ao meio ambiente ecologicamente equilibrado para as presentes e futuras gerações. É necessário atentar para o fato de que esse dispositivo possui "uma conotação multifacetária, porquanto o objeto de proteção verifica-se em pelo menos quatro aspectos distintos (meio ambiente natural, artificial, cultural e do trabalho), os quais preenchem o conceito da sadia qualidade de vida.",16

O ambiente cultural, como faceta do meio ambiente, é, portanto, essencial para o direito constitucional à promoção do bem estar dos moradores da cidade. Nessa esteira se enquadra a proteção do patrimônio cultural:

"Os bens socioambientais alteram e complementam a função social da propriedade, porque agregam elementos funcionais a ela. Uma casa de moradia urbana, que cumpra sua função social por servir de residência, quando tombada como patrimônio cultural, passa a ter também a função social de preservar a

\footnotetext{
${ }^{15}$ PASQUALINI, Alexandre. O Público e o Privado. In: SARLET, Ingo Wolfgang Sarlet (Org.). $O$ Direito Público em Tempos de Crise: Estudos em Homenagem a Ruy Ruben Ruschel. Porto Alegre: Livraria do Advogado, 1999. p. 34-35.

${ }^{16}$ FIORILLO, Celso Antônio Pacheco. Curso de Direito Ambiental Brasileiro. São Paulo: Saraiva, 2000, p. 179.
} 
memória e evocar uma manifestação cultural, isto é, agrega, amplia, a função social da propriedade. A alteração não será apenas por agregar algo a mais, podendo haver mudanças, já que um bem socioambiental teve alterada a sua essência jurídica. (...)

a propriedade urbana está vinculada à função social da cidade que visa, ela mesma, o bem-estar de seus habitantes. O reconhecimento do valor cultural, histórico, paisagístico, artístico, arqueológico, paleontológico, ecológico ou científico agrega por compor o bem-estar dos habitantes das cidades ou o meio ambiente, função social à propriedade." 17

A Constituição prevê o acesso à cultura como direito fundamental, protegida como fenômeno social e fator de emancipação humana.

O acesso à cultura, entretanto, torna-se um problema social, na medida em que se revela apenas a poucos cidadãos, ao invés de ganhar a dimensão universal que deve ter:

"A injustiça cultural [...] é obrigar grupos e manifestações culturais diversos a se submeterem a normas e configurações políticas estanques e imutáveis. À lógica da via única e da política homogênea. Qualquer política de cultura a ser adotada pelo País, deve garantir a abertura dos canais institucionais e financeiros, através da reforma do sistema nacional de cultura, a amplos setores tradicionalmente atendidos pelas 'políticas de recorte social ou assistencialistas' [...] é sintomático que não empreenda, num mundo marcado pelo trânsito incessante de informações, uma política de comunicação cultural capaz de gerar produtos informativos de qualidade para a enorme rede nacional de educação e também para os mercados televisivos e editoriais. Faz-se a política para os empresários e para os artistas renomados nada desprezível, mas insuficiente para o tamanho e a força criadora do País."

A cultura pode ser considerada "privatizada", já que o acesso a cultura não é assegurado na prática pelo Estado, tampouco sendo observado estímulo à produção cultural, ao menos em relação aos indivíduos que tem negado o acesso à cultura por este ser público. Desse modo, os indivíduos não são contemplados quando o direito, enquanto fenômeno cultural, acompanha a dinâmica cultural da sociedade. Esses, apartados da cultura, acabam sendo apartados do próprio direito.

Para o constitucionalista Peter Häberle, que enxerga o Direito como fenômeno cultural, “as forças sociais não podem ser tratadas simplesmente

\footnotetext{
${ }^{17}$ SOUZA FILHO, Carlos Frederico Marés de. Bens Culturais e Proteção Jurídica. Porto Alegre: Unidade Editorial, 1997. p. 20-21.

18 PORTO, Marta. Por uma Política Pública de Cultura: Desenvolvimento e Democracia. In: SCHOLZE, Lia. Reunião Pública Mundial de Cultura. Porto Alegre: Unidade Editorial, 2003, p. 37
} 
como objetos, devendo ser integradas na concepção de Direito e Constituição". 19

Nesse sentido, a atuação dos cidadãos, determinante para a criação do ambiente cultural, deve assumir um papel destacado, especialmente no tocante à produção cultural artística, ficando certo mais uma vez, que o ambiente cultural é infinitamente mais amplo do que sua percepção meramente patrimonial.

É evidente, portanto, que quando uma propriedade privada ou pública promove cultura em seu sentido artístico há um enriquecimento significativo do cumprimento de sua função social, com reflexo direto na efetividade das funções sociais da cidade. Não há dúvidas também de que o indivíduo social, como agente cultural artístico direto, deve ganhar a possibilidade e vir a ser estimulado a contribuir para a produção de um meio ambiente cultural, construindo artisticamente os espaços públicos.

Os conflitos da cidade contemporânea, no que diz respeito à conexão entre arte e a construção de espaços públicos, estão situados num contexto com várias dimensões. Portanto, a questão aparentemente considerada como um problema primário, como a precariedade do ensino público, provoca a expropriação do conhecimento e não deve ser encarada de modo algum como mazela precedente ao limitado acesso à cultura e sim como condição diretamente relacionada.

A Arte, como apontado alhures, possui um efeito gnosiológico, transformador do ponto de vista social, ao transmitir conhecimento e estimular o senso crítico. Numa perspectiva educacional holística constitui elemento de suma importância na construção da cidadania ciente e consciente de seus direitos.

A Arte é poderosa ferramenta para levar cidadania para a população. Vulneráveis, que, em regra, estão excluídos, são considerados “pessoas

\footnotetext{
${ }^{19}$ HÄBERLE, Peter. Teoría de la Constitución como Ciencia de la Cultura. Madrid: Tecnos, 2000 (tradução da segunda edição original, 1996).
} 
absolutamente marginalizadas da sociedade, porque não sabem nem mesmo os direitos de que dispõem ou de como exercê-los". ${ }^{20}$

$\mathrm{O}$ acesso à cultura ganha novos espaços quando a arte é desenvolvida de forma pública para integrar indivíduo, comunidade, criando e reforçando o sentimento de inclusão social.

\subsubsection{Direito Urbanístico brasileiro e Direito à Cidade: o microssistema do Estatuto da Cidade}

O Direito Urbanístico brasileiro constitui um campo relativamente novo. O seu principal marco normativo de institucionalização é a Constituição de 1988 através dos seus arts. 182 e 183. Considerando que o seu núcleo principal é constituído pelo direito à cidade. ${ }^{21}$

A relevância do Estatuto da Cidade ao estabelecer princípios e diretrizes que devem ser aplicados nos planos diretores ${ }^{22}$, diz respeito a sua natureza de microssistema.

O Plano Diretor é o instrumento básico da política de desenvolvimento e de expansão urbana. $^{23}$ Portanto, na política e nos conflitos atinentes ao desenvolvimento urbano, a aplicação do Estatuto da Cidade tem prevalência sobre a lei geral (Código Civil). Deste modo, sua

\footnotetext{
${ }^{20}$ CARNEIRO, Paulo Cezar Pinheiro, 1999, p. 58

${ }^{21}$ Cavallazzi, Rosangela.

22 Art. 41 - O plano diretor é obrigatório para cidades:

I- $\quad$ com mais de 20000 (vinte mil) habitantes;

II- $\quad$ integrantes de regiões metropolitanas e aglomerações urbanas;

III- onde o Poder Público municipal pretenda utilizar os instrumentos previstos no parágrafo $4^{\circ}$ do Art. 182 da Constituição Federal;

IV- $\quad$ integrantes de área de especial interesse turístico;

V- inseridas na área de influência de empreendimentos ou atividades com significativo impacto ambiental de âmbito regional ou nacional;

VI- incluídas no cadastro nacional de Municípios com áreas suscetíveis à ocorrência de deslizamentos de grande impacto, inundações bruscas ou processos geológicos ou hidrológicos correlatos.

${ }^{23}$ BONIZZATO, Luigi. Constituição, Democracia e o Plano Diretor - Sob o influxo dos direitos sociais e de liberdade, políticas estatais e institucionais.
} 
aplicação, na qualidade de microssistema, garante os direitos sociais fundamentais.

Os microssistemas pressupõem o reconhecimento de relações de desigualdades.

O microssistema, largamente estudado no campo do Direito do Consumidor por Claudia Lima Marques ${ }^{24}$ inclusive articulado com o método do diálogo das fontes ${ }^{25}$, tem sido considerado no campo do Direito Urbanístico por Rosângela Cavallazzi em relação ao Estatuto da Cidade.

Segundo Cavallazzi, no campo do Direito Urbanístico o microssistema do Estatuto da Cidade, para os vulneráveis, no processo de interpretação tem contribuído de forma essencial para eficácia social da norma urbanística, sem conflito com o Código Civil de 2002, na qualidade de lei geral. ${ }^{26}$

Na concepção de CAVALLAZZI "as construções normativas em projetos devem assumir princípios e diretrizes que estejam em consonância com o Estatuto da Cidade, microssistema normativo que estabelece a tutela das relações entre desiguais, protegendo os vulneráveis." 27

A contextualização do Direito à Cidade no âmbito dos conflitos urbanos, portanto tem contado, portanto com o Estatuto da Cidade, na

\footnotetext{
${ }^{24} \mathrm{O}$ CDC é um microssistema especial, um código para a gentes "diferentes" da sociedade, ou consumidores, em relação entre "diferentes" (um vulnerável, o

consumidor, e um expert, o fornecedor). Já o CC/2002 é um código geral, um código para os iguais, para relações entre iguais,civis e empresariais".: MARQUES, 2005, p. 22. MARQUES, Cláudia Lima. Diálogos entre o CDC e o CC/2002. In: PFEFFEIR, Roberto A C.; PASQUALOTTO, Adalberto (Coords.). Código de Defesa do Consumidor e o Código Civil de 2002. convergências e assimetrias. Rio de Janeiro: Revista dos Tribunais, 2005 v. 26 p. 22.

Ver também sobre a matéria PASQUALOTTO. A. S. O Código de Defesa do Consumido em face do Código Civil de 2002, In: PFEFFEIR, Roberto A. C.; PASQUALOTTO, Adalberto (Coords.). Código de Defesa do Consumidor e o Código Civil de 2002:convergências e assimetrias. Rio de Janeiro: Revista dos Tribunais, 2005, p. 131-132

${ }^{25}$ CAVALLAZZI, Rosangela. Projeto de Pesquisa Paisagem Urbana: construções normativas em projetos urbanos. Relatório CNPq. PROURB- UFRJ. Rio de Janeiro. 2014.

${ }^{26}$ Ibid.

${ }^{27}$ CAVALLAZZI, Rosângela Lunardelli . Projeto Dinâmicas territoriais contemporâneas $e$ direitos sociais em grandes projetos urbanos metropolitanos: Desafios da cidade standard.Edital PRIORIDADE RIO - FAPERJ. Rio de Janeiro. 2014.
} 
qualidade de microssistema, como um grande aliado, inclusive para a consolidação do campo do Direito Urbanístico.

\subsubsection{Vulnerabilidades e o feixe de direitos sociais que compõem o Direito à Cidade}

Há uma busca constante por relações de confiança na cidade.

"Esta relação de confiança implica na composição cotidiana das condições de dignidade (direito a moradia, saúde, trabalho), entrelaçada com as condições da liberdade (direito a informação, educação, serviços públicos - implícito o saneamento -, lazer e segurança), e com as condições de confiança no futuro (preservação do patrimônio cultural, histórico e paisagístico, ao meio ambiente natural e construído equilibrado, implícita a garantia do direito a cidades sustentáveis)., 28

Os direitos fundamentais e sociais, são aqueles que exigem do Estado uma atuação positiva no sentido de implementar a igualdade social dos hipossuficientes.

José Afonso da Silva conceitua os direitos fundamentais como sendo:

"prestações positivas proporcionadas pelo Estado direta ou indiretamente, enunciadas em normas constitucionais, que possibilitam melhores condições de vida aos mais fracos, direitos que tendem a realizar a igualização de situações sociais desiguais. São, portanto, direitos que se ligam ao direito de igualdade, 29

No caso dos direitos sociais que compõem o Direito à cidade, a efetividade de um desses direitos é importante e de imediato indica tutela jurídica, entretanto, a realização do Direito à cidade somente ocorre quando, articuladamente, todos os direitos sociais que constituem o feixe de direitos são efetivados. ${ }^{30}$

\footnotetext{
28 Cavallazzi, Rosangela. Perspectivas Contemporâneas Do Patrimônio Cultural: Paisagem Urbana E Tombamento.2010. p 30

${ }^{29}$ SILVA. José Afonso da. Direito Const. Positivo, Malheiros Ed., 15ª ed., 1998, p. 289.

${ }^{30}$ Cavallazzi, Rosangela. Op.cit. pp 10-25
} 
O processo de fragmentação da norma e da forma urbana, presente no contexto atual da globalização, gera espacialização dos riscos urbanos e fragiliza os direitos que compõem o Direito à cidade. ${ }^{31}$

"Chamo a atenção para a natureza desse conceito, um sistema que forma um feixe de direitos, ou seja, a soma desses direitos. Não são direitos individuais que estarão lado a lado, isoladamente, segundo a lógica dos direitos individuais. Com o status de direito coletivo, estarão devidamente articulados, imbricados, constituindo um outro lugar, um outro momento do próprio Direito à Cidade. Feixe de direitos que, em virtude da sua articulação, redimensiona a capacidade de eficácia social da norma. ${ }^{32}$,

Nota-se, nas práticas sociais, raro espaço que mantém ainda unidade e identidade, fazendo com que devam ser observadas sob a perspectiva de cada contexto garantindo a eficácia dos direitos para a coletividade

\footnotetext{
${ }^{31}$ CAVALLAZZI, Rosangela Lunardelli. O Plano da Plasticidade na teoria Contratual. Tese de Doutorado, UFRJ, 1993.

32 "Ces déplacements dans les temps, dans les cultures et civilisations, dans des domaines de savoirs et disciplines très différentes, mais aussi dans les espaces, laissent voir que les lois mêmes, concernant le patrimoine sont tributaires de cette mobilité et qu'il a fallu le 'sédentariser', pour des raisons scientifiques, et simultanément, pour le 'naturaliser'et le rendre national." TSIOMIS, VIOLEAU e MANTZIARAS (1998, p. 54) - PERSPECTIVAS CONTEMPORÂNEAS DO PATRIMÔNIO CULTURAL: PAISAGEM URBANA E TOMBAMENTO - Rosângela Lunardelli Cavallazzi
} 


\section{Conexão entre Arte e Direito e seu efeito potencializador da tutela de Direitos}

A posição dominante na estética marxista é de que a Arte constituía um "reflexo" ou uma imagem aproximativamente fiel da realidade, um desvendamento da realidade em seus níveis mais essenciais. $\mathrm{O}$ estudo que afirma que a Arte deve procurar refletir o real em sua essência ${ }^{33}$, cria caminhos para que a Arte possa reconhecer os direitos violados e representá-los de forma a contribuir para a inversão de tais violações.

Em trecho do filme "Utopia e Barbárie", de Silvio Tendler, ao perguntar a Augusto Boal sobre ele ser um artista engajado, o mesmo responde:

\footnotetext{
"Não, eu sou um cidadão engajado. E como eu sou um cidadão engajado, como artista é claro que a minha arte não vai ser etérea. Eu tenho que trabalhar e pensar na realidade na qual eu vivo. Eu acho que todo mundo tem que ser engajado, todo o cidadão que vive em sociedade. Eu sempre digo que viver em sociedade não é andar por aí, isso é vegetar em sociedade. Eu acho que o verdadeiro cidadão não é o que vive em sociedade é aquele que transforma a sociedade." ${ }^{34}$
}

A partir dessa afirmação de Boal, com a qual estamos estabelecemos um alicerce em nossa monografia em consonância com o estudo feito por Leandro Konder sobre os Marxistas e a Arte, reconhecemos que devemos validar o conhecimento sobre o objeto a partir do olhar do sujeito $\operatorname{cognoscente}^{35}$, ou seja, daquele que conhece de fato o objeto. Cabem, então, aqueles que vivem a questão, problematizar e descobrir hipóteses de soluções das mesmas através das formas e ferramentas que tiverem para expressar e comunicar o problema vivido.

\footnotetext{
${ }^{33}$ KONDER, Leandro. Os Marxistas e a arte. p. 22

34 Filme "Utopia e Barbárie", de Silvio Tendler 1:48:45 a 1:49:16 https://www.youtube.com/watch?v=cn9li_NePro

${ }^{35}$ A gnoseologia estuda a capacidade humana de conhecer, de apreender a partir da consciência, contato e experiência com o real, tornando verossimilhante as informações. 33
} 
Contrário ao posicionamento que afirma que a arte é pura contemplação contrapõe-se o de que a arte apresenta uma visão de mundo em transformação sendo, então, inevitavelmente política ao apresentar meios de efetivar essa transformação. ${ }^{36}$ "A Arte contem em si mesma polaridade de tendências estáticas e dinâmicas, conservadoras e progressivas, formalistas e anti formalistas.",37

Hauser $^{38}$, ao afirmar isso nos mostra, apresentando os antagonismos presentes na arte com um grande leque de possibilidades e características que podem ser tanto imobilizadoras, quanto impulsionadoras de um novo pensamento.

A partir das reflexões referentes aos conceitos do Direito a cidade e do feixe de direitos que decorrem do mesmo, anteriormente, pode ser então entendido e criado um caminho no sentido de sua eficácia, a partir de uma análise da voz da sociedade expressa através do cinema, teatro e arte urbana; artes estas que podem representar um momento e núcleo de grupos sociais e estimular um desenvolvimento da faculdade de pensar por meio de conceitos, atrelado a faculdade de sentir, que humaniza o homem no sentido da formação do ser humano ${ }^{39}$.

A partir disso percebemos que a arte pode interferir diretamente em muitos caminhos e formas que o Direito pode seguir, como apresenta Boal no Teatro do Oprimido e no Teatro do Legislativo demonstram o e o pensamento de Leandro Konder que a arte desperta novos pensamentos sobre uma mesma realidade, podendo ser, então, um grande registro e uma grande motivação ao conhecimento jurídico. Esta motivação no que diz respeito ao espaço da cidade, permite uma possibilidade de seu melhor aproveitamento do espaço urbano como plataforma de informações aos vulneráveis que precisam ter seus direitos tutelados, além de formas mais

\footnotetext{
${ }^{36}$ BOAL, Augusto. Teatro do Oprimido. Civilização brasileira p. 36

${ }^{37}$ HAUSER, Arnold. História Social da Arte e da Literatura. 1998. p.259

${ }^{38}$ Ibid. 250-265

${ }^{39}$ KONDER, Leandro. Os marxistas e a arte. p. 39
} 
favoráveis a apresentar, informar e transformar ambientes sociais para facilitar uma conscientização através da arte direcionada, vindo a tutelar o direito dos vulneráveis.

Como reconhece $\mathrm{Hegel}^{40}$, em sentido contrário ao pensamento de Jean Jacques Rousseau, a arte tem efetivamente contribuído para o aperfeiçoamento moral do homem. ${ }^{41}$ As transformações na arte, desde seu reconhecimento, acompanharam as transformações da sociedade e continuam acompanhando. Isso mantém forte sua função política que garante os direitos sociais pelos quais elas lutam, humanizando os excluídos que vêem seus direitos sendo violados a todo instante.

A arte sempre esteve presente na história da humanidade com forte poder transformador; logo quando o poder político desassocia política da arte, como aconteceu fortemente no período da ditadura militar no Brasil, pois não queriam os chefes de poder que a arte fosse a grande transmissora de informações, por exemplo. Ela ganha ainda mais força como um catalisador de transformações.

Os estudos de Margot Berthold ${ }^{42}$, Augusto Boal e Leandro Konder, dentre outros, sobre a história do teatro, do cinema e da arte urbana confirmam a existência de diversos métodos para utilizá-los de forma a tornar possível a influência no âmbito jurídico; evitando a presente tendência a esvaziar o Direito de todo conteúdo humanístico, o que o deixa imobilizado por pela força do formalismo estático.

A arte pode transformar a compreensão em relação à necessidade das pessoas buscarem formas de superar a dura realidade das normas legais, as quais, quando tem sua constitucionalidade observada não pode se limitar ao exame de sua validade em tese, devendo estender-se sob às conseqüências de sua aplicação no caso concreto. Quando uma lei ferir a dignidade da

\footnotetext{
${ }^{40}$ KONDER, Leandro. Os Marxistas e a Arte p.29 - 36

${ }^{41}$ Ibid. p. 34

${ }^{42}$ BERTHOLD, Margot. História Mundial do teatro. $4^{\mathrm{a}}$ ed. São Paulo:Perspectiva, 2010.
} 
pessoa humana quando aplicada ao caso concreto, mesmo que tecnicamente compatível com a Constituição, deve ter sua aplicação negada pelo judiciário.

A Constituição jacobina francesa de 1793 , que surgiu no período da Revolução Francesa transformando os direitos sociais, considerou "o mais sagrado dos direitos e o mais indispensável dos deveres, em seu artigo 35, o exercício da "resistência à opressão". 43

Reale afirma, ainda:

"e note-se que o futuro não se atualiza como pensamento, para inserir-se no homem como ato, - caso em que deixaria de ser futuro - mas se revela em nosso ser como possibilidade, tensão, abertura para o projetar-se intencional de nossa consciência, em uma gama constitutiva de valores." ${ }^{44}$

Mostra o referido autor, em afirmação, que não somos apenas espectadores da vida, e sim verdadeiros e potenciais agentes ativos que podem transformar o futuro consideravelmente a partir de nossas ações.

Partindo dos estudos sobre a relação entre os movimentos artísticos e efetivas mudanças políticas, reforçamos que o conhecimento artístico é de inegável validade cultural. Legitimado pela influência prática que alcança na vida cultural dos povos e da qual a história da arte testemunha, devemos ter consciência para diferenciar ações episódicas das efetivamente transformadoras. $^{45}$ É reconhecido que forças políticas empenhadas na transformação revolucionária, ao redor do mundo em que vivemos, tem a política cultural forte.

\footnotetext{
${ }^{43}$ Constituição jacobina francesa de 1793

${ }^{44}$ REALE, Miguel. Paradigmas da Cultura Contemporânea,1996. p.67

${ }^{45}$ Konder, Leandro. Os Marxistas e a Arte. p. 22-24
} 


\subsection{Teatro}

Augusto Boal, que diz que o teatro deve ser um ensaio para ação na vida real, e não um fim em si mesmo ${ }^{46}$, confirma assim a capacidade de retro alimentação entre Direito e Arte, na forma de Teatro.

O autor trata o espetáculo como início de uma transformação social necessária e não um momento de equilíbrio e a repouso. Seguindo esta concepção de que o Teatro deve despertar pensamentos e ideias, iremos falar do Teatro, a partir da ótica do Teatro do Oprimido,

Em 1980, o autor, diretor e dramaturgo afirma, ainda, em entrevista que:

O Teatro surge como uma necessidade do homem a partir de seu desenvolvimento.

Em período anterior a existência de acesso aos meios de comunicação digitais conhecidos hoje, o homem buscou se comunicar com seu grupo a partir de formas que tinham maior alcance possível.

No surgimento do Teatro, como apresenta Margot Berthold em seu livro História Mundial do Teatro ${ }^{47}$, acreditava-se que por meio desses rituais era possível invocar deuses e forças da natureza para fazer chover, tornar a terra mais fértil e as caças mais fáceis, ou deixar os desastres naturais bem longe de sua comunidade.

Ainda no livro da referida autora, percebemos que com a entrada das tragédias gregas, os temas passaram a ser ligados às leis, à justiça e ao destino. É a luta que gera a demanda. ${ }^{48} \mathrm{O}$ grande potencial político, então observado, do Teatro, faz com que seja trabalhado o uso do mesmo dentro desses grupos de forma a despertar o interesse de todos aos assuntos

\footnotetext{
${ }^{46}$ BOAL, Augusto. Teatro do Oprimido, p. 19

${ }^{47}$ BERTHOLD, Margot. Perspectiva, $4^{\mathrm{a}}$ ed. São Paulo: 2010. pp33-40

${ }^{48}$ BERTHOLD, Margot. História Mundial do Teatro, p, 29-40
} 
abordados por ele, e que possam gerar efetivos resultados por aqueles que participarem desse entendimento.

Acompanhando a história do Teatro brasileiro, notamos diversos marcos essenciais para que possa ser entendida essa história.

O Decreto assinado pelo rei D. José I, no Palácio da Ajuda, em Lisboa, em 17 de julho de 1771, e assinado por Marquês de Pombal, certamente obra do mesmo, foi inovador sob muitos aspectos. Ele, dentre outras coisas, refere-se ao fato de que os "teatros públicos (...) quando bem regulados são escolas onde os povos aprendem as máximas da política, da moral, do amor da pátria, do valor, do zelo e da fidelidade com que devem servir seus soberanos." 49

Esse Decreto nos mostra que há mais de 200 anos o Teatro já era pensado como prática influente e transformadora; como forma de arte com valor cognoscitivo que proporciona conhecimento e consegue acessar pessoas que estão dispostas a aprender e apreender o conhecimento transmitido através dessa manifestação artística.

No Brasil, alguns anos depois, no período republicano, podemos reparar o mesmo caráter identificado anteriormente em Portugal. Foi promulgado o Decreto Lei n. 2557 de 21 de julho de 1987, decretando seus Arts. $2^{\circ}$ que:

"para execução das peças teatrais e exibições em casas de espetáculo, a polícia cingir-se-á a tomar conhecimento, com antecedência, da peça ou do programa que tiver de ser executado, cabendo-lhe proibir ou suspender o espetáculo se verificar que dele possam resultar perturbação da ordem pública ou ofensas ao decoro público e no $3^{\circ}$, que "ficando revogadas as disposições em contrário." 50

Essa decisão, que afasta temporariamente do teatro sua função efetivamente transformadora ou educadora, visto que seus assuntos não poderiam ser integralmente abordados em cena de uma forma livre, se

\footnotetext{
${ }^{49}$ Decreto assinado pelo rei D. José I, no Palácio da Ajuda, em Lisboa, em 17 de julho de 1771, e assinado por Marquês de Pombal

${ }^{50}$ PAIXÃO, pp.488-489
} 
mantem até a extinção da censura, com a promulgação da Constituição Federal brasileira, de 1988.

No Brasil, no auge da ditadura militar ${ }^{51}$, muitos daqueles que estavam ligados a arte de encenar, foram presos, torturados e muitas vezes até expulsos do país ${ }^{52}$ o que mostra que de fato estava o teatro representando a realidade daquele momento, e a transmissão dessas informações não condizia com as práticas do governo, que não respeitava a liberdade de expressão.

A partir do realismo ${ }^{53}$ e naturalismo o Teatro brasileiro cada vez mais assume seu papel de instrumento de discussão e crítica da sociedade a medida que se aproxima da realidade. O Teatro nessa época ilustra a realidade social; trabalha questões políticas e questões que refletem criticamente aspectos da sociedade vigente. ${ }^{54}$ Berthold relata que havia um dever de "levar ao palco uma realidade que explicasse todo o comportamento humano". 55

Augusto Boal estava entre os que acreditavam em uma transformação e reforma a partir de manifestos artísticos. Teve seu espaço, que funcionava desde 1956 no Rio de Janeiro e foi fechado em 1970 e em seguida sofreu com perseguições políticas, tortura, até que foi expulso do país no mesmo ano.

A partir doa registros documentais acessíveis, como a doutrina estudada, pode-se perceber aspectos nas leis que regulamentam a atividade

\footnotetext{
${ }^{51}$ Para legitimar o Golpe Militar deferido em março de 1964, os generais que permaneceram na presidência durante o período entre 1964 e 1969 se valeram de decretos para garantir direitos políticos inválidos pela Constituição vigente, conhecidos como Atos Institucionais (AI's). Um conjunto de ações marcaram a instalação da Ditadura Militar no país. Os AI's eram validados sem consulta popular ou legislativa, servindo como mecanismos para ampliação da censura e fortalecimento da autoridade dos militares.

${ }^{52}$ Anistia Internacional. Tortura: informe da Anistia Internacional. Madrid:Fundamentos. 1984

${ }^{53}$ O Realismo e o Naturalismo apresentam semelhanças e diferenças entre si. O Realismo retrata o homem interagindo com seu meio social, enquanto o Naturalismo mostra o homem como produto de forças "naturais", desenvolve temas voltados para a análise do comportamento patológico do homem.

> http://www.brasilescola.com/literatura/o-naturalismo.htm >>Acesso em:10/10/2014

$54 \mathrm{http}: / /$ www.arte.seed.pr.gov.br/modules/conteudo/conteudo.php?conteudo=179 > Acesso em: 10/09/2014.

${ }^{55}$ BERTHOLD, Margot. História Mundial do Teatro, p. 451
} 
teatral no Brasil. A preocupação em controlar, junto à censura, e extensiva aos autores e espetáculos, é seguida de determinações subsidiárias que tem por objetivo consolidar o "teatro nacional". Continuaremos abordando o Teatro que se utiliza de ferramentas e técnicas que efetivamente possam influenciar e transformar a consciência jurídica de grupos sociais.

O Teatro do Oprimido, segundo Augusto Boal, luta a partir de três campos: palavra, imagem e som. Essa forma de teatro, apesar de possuir estudos, técnicas e formas de acontecerem precisas e objetivas, além de bem fundamentadas, não tem objetivo de vender única e exclusivamente uma técnica, mas de instrumentalizar grupos para que estes, a partir disso, possam exercer o poder transformador em suas comunidades.

Uma das técnicas do teatro do oprimido é a de aproximação do público ao real, através da qual se dramatizaram as notícias da imprensa cotidiana, procurando, através da teatralização, enfatizar o intuito manipulador da impressa, recebe o nome de Teatro de Jornal.

A técnica foi utilizada no Brasil pelo Teatro de Arena, em São Paulo, em $1970^{56}$, e pretendia provar que qualquer pessoa, mesmo que não fosse artista, pode fazer do teatro um meio de comunicação. Esses espetáculos nacionais fecharam as portas para a dramaturgia estrangeira, abrindo para quem quisesse falar do Brasil, as plateias brasileiras. Eles dividem-se em clássicos e revolucionários, sendo os primeiros responsáveis por desenvolver e cristalizar um mesmo estilo através de vários espetáculos; enquanto, o segundo, feito por etapas que não se cristalizam nunca e se sucedem no tempo, necessariamente coordenada. A coordenação é artística e a necessidade social. ${ }^{57}$

Boal desenvolve outra técnica dentro do teatro do oprimido, o teatro do legislativo. Essa forma de teatro surge nos anos que foi, inclusive, vereador da Cidade do Rio de Janeiro, entre 1992 e 1996. Esse surgimento

\footnotetext{
${ }^{56}$ BOAL, Augusto. Teatro do Oprimido. Civilização Brasileira. p.52

${ }^{57}$ BOAL, Augusto. Teatro do Oprimido. pp. 242-254.
} 
se deu em conjunto com uma prática legislativa, na qual os problemas da população passam a ser discutidos constituindo um fórum para propor leis capazes de interferir diretamente em situações de opressão.

O Teatro do Oprimido tornou-se uma prática conhecida em todo o mundo, usado tanto na saúde mental como em prisões e hospitais, em escolas e em comunidades na África ou América Central. ${ }^{58}$

A dinâmica do Teatro do Oprimido cria o espaço para conscientizar sobre a importância do cumprimento da norma, ampliando a possibilidade da legitimidade aplicada da norma, além de pensar as normas para cada realidade apresentada. É uma busca coletiva por soluções e propostas, portanto sua importância para a consciência das questões urbanas, especialmente as que dizem respeito a paisagem urbana e a eficácia dos direitos sociais que constituem o Direito à Cidade.

O potencial da Arte para a direitos conscientização é muito importante para enfrentar os desafios da lógica uniformizadora da norma.

A normatização e institucionalização do fazer teatral gera um campo conflituoso com as liberdades artísticas que, por sua vez, está ligada à liberdade de invenção de sua própria subjetividade.

Portanto, muitas vezes a uniformização da Arte, ao desconsiderar sua historicidade e criatividade, inviabiliza, no lugar de incentivar o espaço da transformação social.

A Lei Rouanet, por exemplo, pode limitar a criatividade do teatro na medida que o poder público transfere para empresas a decisão de onde investir. Assim, muitas vezes, se o assunto não está de acordo com o interesse de empresas, torna-se mais difícil conseguir o apoio muitas vezes necessário para que um espetáculo teatral se torne possível. Para que o pensamento criativo não acabe sendo substituído pelo publicitário e para que o artista que busca no povo sua inspiração e destino não fique

\footnotetext{
${ }^{58}$ BOAL, Augusto. Arte, Pedagogia e Política. p 26.
} 
impossibilitado de viabilizar o acontecimento de sua Arte, é necessário também, que haja formas de apoio que venham de órgãos públicos. Sendo assim, direitos sociais decorrentes do direito à cidade estariam sendo respeitados facilitando o cumprimento da função social do Teatro proposta.

Os direitos sociais que compõem o feixe de direitos do Direito à Cidade, incluem o direito à educação, serviços públicos, lazer, e de preservação do Patrimônio Cultural, histórico e paisagístico e acabam por ser violados ao tornar artistas e cidadãos que buscam a transformação da sociedade $^{59}$ em dependentes desse investimento e aprovações de empresas privadas.

Vale ressaltar, mesmo que a rigor não seja possível a comparação de dois tempos tão distintos, que, desde a antiguidade, guardadas as devidas proporções, os teatros aconteciam nas principais cenas da vida pública, enquanto hoje ocorrem, em sua maioria, nas salas fechadas, o que prejudica o alcance do teatro político, que pode ser maior e influenciar uma maior quantidade de pessoas.

\subsection{Cinema}

O desenvolvimento da comunicação de massa possibilitou o aparecimento de novas possibilidades teatrais e a difusão desse trabalho, em um mundo cada vez mais global e conectado.

Aparelhos que projetavam imagens em movimento sugiram como mais uma curiosidade entre as criações do final do século XIX. Não se pode dizer que existiu um único inventor do cinema, foram constantes as transformações da aparelhagem cinematográfica. Segundo Costa, "os aparatos que a invenção envolve não surgiram repentinamente em um único lugar" ${ }^{\circ 0}$.

\footnotetext{
${ }^{59}$ BOAL, Augusto. Teatro do Oprimido pp. 50-65

${ }^{60}$ COSTA, Flávia Cesarino. História do cinema mundial. 2006. $4^{\mathrm{a}}$ ed. Campinas, SP: Papirus, p.19
} 
Os irmãos Lumiére realizaram uma demonstração de seu cinematógrafo em um evento público, mas pago. Os irmãos gostavam de documentar cenas da realidade cotidiana em locações naturais, externas e autênticas. Essa não foi a primeira projeção de filmes, Thomas Edison e os irmão Skaladanowky já haviam realizado projeções antes. A projeção de $A$ saída dos operários da Fábrica Lumiére $(1895)^{61}$, filmada por uma câmera oculta, exibida no Grand Café de Paris era composta por uma única tomada e sem uma narrativa estruturada e foi considerada um marco na historiografia cinematográfica.

Costa afirma que seus filmes são a origem do que seria chamado "realismo documentário". ${ }^{62}$ A imagem de operários saindo da fábrica após um dia de trabalho, cena rotineira no cotidiano da cidade de Lyon, no final do século XIX, tem como cenário pessoas comuns e ações comuns.

A ideia do cinema desde seu início era a de representar o real, o registro dessas imagens cotidianas são a comprovação disso. De acordo com Andrew (1989, p. 36), “a maioria dos teóricos tem afirmado que até certo ponto o cinema é veículo da realidade, mesmo sendo substituição do real".

O cinema é abordado tendo em vista sua história, linguagem e especificidades; acompanhando as transformações da realidade social que o cerca.

No Brasil, a Embrafilme (Empresa Brasileira de Filmes Sociedade Anônima), uma estatal brasileira produtora e distribuidora cinematográfica, foi criada em setembro de 1969 pelo Decreto-lei $\mathrm{N}^{\mathrm{o}}$ 862. Primeiramente criada para promover o cinema brasileiro no exterior, logo passou a também fomentar a produção e a distribuição de filmes nacionais. O Estado passa, então, a financiar diretamente os cineastas brasileiros. No início dos anos 90, os ingressos para o cinema se tornaram mais caros e ao número de salas

\footnotetext{
${ }^{61}$ Com o titulo original La sortie des usines Lumiére, Em 28 de dezembro de 1895.

${ }^{62}$ COSTA, Flávia Cesarino. História do cinema mundial. 2006. $4^{\mathrm{a}}$ ed. Campinas, SP: Papirus, p. 19
} 
foi reduzido. A extinção da Embrafilme em março de 1990, se deu devido ao Programa Nacional de Desestatização, do governo Collor. Explicar melhor este processo e toda a conjuntura política

A extinção desse órgão cultural e de outros, provocou os piores anos da história do cinema. Nagib ${ }^{63}$ relata que "em 1992, apenas dois filmes de longa-metragem foram lançados no Brasil’.

"A expressão 'retomada', que ressoa como um boom ou um 'movimento' cinematográfico, está longe de alcançar unanimidade mesmo entre seus participantes. Para alguns, o que houve foi apenas uma breve interrupção da atividade cinematográfica com o fechamento da Embrafilme, a seguir reiniciada com o rateio dos próprios recursos da produtora extinta, através do Prêmio Resgate Brasileiro". ${ }^{64}$

O Prêmio Resgate do Cinema Brasileiro contemplou 90 projetos cinematográficos, entre curtas, médias e longas-metragens. A Lei $\mathrm{N}^{\mathrm{o}} 8.585$, mais conhecida como Lei do Audiovisual, promulgada em 1993 passar a conceder efetivos fiscais efetivamente em 1995. A referida lei viabilizou o crescimento da produção cinematográfica brasileira e a produção de filmes nacionais aumentou gradativamente. O cinema é abordado tendo em vista sua história, linguagem e especificidades; acompanhando as transformações da realidade social que o cerca.

Esse período representou um grande momento na produção audiovisual no Brasil, filmes com temáticas nacionais, contando a história do país, como Carlota Joaquina, Princesa do Brazil (1995), de Carla Camurati, representam um marco dessa chamada retomada do cinema brasileiro. Em geral, os temas dos filmes são ligados à contraditórias questões sociais, pobreza, corrupção, violência e o cotidiano do sertão ou das favelas. O cinema de retomada levou as tragédias sociais para as telas a partir do resgate da realidade urbana e as contradições sociais da sociedade brasileira e a violência urbana tão presente no cotidiano da população.

\footnotetext{
${ }^{63}$ NAGIB, Lúcia. $O$ cinema da retomada. Depoimentos de 90 cineastas dos anos 90. São Paulo: 34, Editora, 2002. p.13

${ }^{64}$ Ibid. p. 13
} 
Filmes como Central do Brasil (1998), de Walter Salles, e Cidade de Deus (2002), de Fernando Meirelles, são fortes exemplos,

Nos anos 2000, a ANCINE é criada em substituição à Embrafilme, para ser o órgão gestor de atividade cinematográfica oficial do governo federal. Todos esses fatores proporcionaram uma abertura democrática no panorama cinematográfico nacional.

Além disso percebemos, na atual geração que tem fácil acesso a meios de comunicação e tecnologia, uma busca de informação de diversos tipos. O cinema, grande formador de opinião no mundo contemporâneo, figura como importante veículo pela facilidade e objetividade de sua comunicação, além de grande e imediato alcance, e, portando, forte potencial transformador.

O filme Art of Conflict, ${ }^{65}$ por exemplo, mostra a história dos milhares de muros pintados contando coletivamente a história dos conflitos da Irlanda do Norte nos últimos 50 anos. Durante esse período, ${ }^{66}$ qualquer tentativa de propaganda ou de divulgação de opiniões era rapidamente oprimida. Como forma de manifestação as pessoas usavam a arte urbana para mostrar ao mundo o que realmente estava acontecendo em sua comunidade, para mostrar seus pontos de vista de acordo com os direitos sociais que deveriam lhes ser garantidos.

Esses muros eram uma expressão artística muito politizada e ampliaram a consciência e a alma daquela sociedade. Renovar os murais podia ser entendido como renovar uma identidade imposta. Existiam mensagens positivas sociais com visão de futuro nesses muros, como uma que dizia Não procuramos nada além de direito fundamental, do direito de

\footnotetext{
65 Dirigido por Valeri Vaughn, com Owen Thomas. Os murais da Irlanda do Norte são uma expressão da violência local vivida e testemunhada pelos moradores.

66 Em 1972, mais de uma dezena de jovens irlandeses católicos foram mortos no Domingo Sangrento. Em 30 anos de conflito, cerca de 3.600 pessoas morreram na Irlanda.
} 
se defender se for atacado, ${ }^{67}$ buscando única e exclusivamente pela eficácia dos direitos sociais. ${ }^{68}$

Outros filmes, como PIXO ${ }^{69}$, defendem ainda, que Querem somente que alguém olhe para eles para contribuir de alguma forma para que a existência não se torne nula ${ }^{70}$. Muitas vezes a pichação ${ }^{71}$ aparece somente como uma forma de agredir a sociedade, não se comunicando com a mesma. $^{72}$

O documentário TORRE DE DAVID - A VIDA NA MAIOR FAVELA VERTICAL DO MUNDO ${ }^{73}$ - realizado pelos repórteres Julio Molica e Rodrigo Carvalho, mostra um edifício na Venezuela que, após abandonado por 18 anos, é ocupado por 4000 pessoas alocadas ao longo de 28 andares. Torna-se um conjunto habitacional ocupado de forma a cumprir sua função social e onde o feixe de direitos decorrente do direito à cidade passa a ser respeitado. O Governo boliviano, no caso em tela, promove uma politica conhecida popularmente como A Grande Missão Habitação Venezuelana. Deixando de lado o mecanismo de exclusão econômica, proporcionado pelo capitalismo, nesse espaço ocorre a ocupação através de diversas formas tais como a disponibilidade de prática de esportes, aulas de dança, espaços para artes, consultas médicas, moradia, espaços para trabalho, palestras educativas, dentre outros. Há uma necessidade de buscar

\footnotetext{
${ }^{67}$ Filme Art of Conflict

${ }^{68}$ Art of Conflict.

${ }^{69}$ Filme - Pixo - Documentário Sobre Pichação e Pichadores. O impacto da pichação como fenômeno cultural na cidade de São Paulo e sua influência internacional como uma das principais correntes da Street Art. O filme participou da exposição Né dans la Rue (Nascido na Rua), da Fondation Cartier pour l'Art Contemporain, em Paris. O documentário mostra a realidade dos pichadores, acompanha algumas ações, os conflitos com a polícia e mostra um outro olhar sobre algumas intervenções já muito exploradas pela mídia. O filme não traz respostas, mas fornece argumentos para o debate: pichação é arte ou é crime?

${ }^{70}$ Filme - Pixo - Documentário Sobre Pichação e Pichadores

${ }^{71}$ Pichação, visto por muitos na sociedade como apenas um ato de "Vandalismo", porém para os próprios pichadores tem outros sentidos, tais como: "Liberdade, manifestação, transgressão, protesto, arte, etc.."

${ }^{72}$ PIXO, Filme.

${ }^{73}$ TORRE DE DAVID - A VIDA NA MAIOR FAVELA VERTICAL DO MUNDO

http://globotv.globo.com/globonews/globonews-documentario/v/torre-de-david-mostra-a-vidana-maior-favela-vertical-do-mundo/3741949/
} 
soluções que podem ser realizadas; tendo como principal foco o ser humano, e como secundário a estrutura.

Podemos estabelecer um paralelo com outro exemplo atual que passa a ocorrer em terras brasileiras.

São Paulo é a primeira cidade a implantar a ferramenta prevista na Constituição Federal Brasileira de 1988, no artigo $182^{74}$. Através do decreto $\mathrm{n}^{\mathrm{o}} 55.638$, de 30 de outubro de 2014, que confere nova regulamentação à aplicação dos instrumentos indutores da função social da propriedade urbana no Município de São Paulo, em especial à notificação para o parcelamento, edificação e utilização compulsórios; e revoga o Decreto $n^{o}$ 51.920, de 11 de novembro de 2010, há uma tentativa de recuperar a função social do imóvel, prevista no plano diretor estratégico, sancionado em julho de 2014.

Os imóveis que não cumprem sua função de construir ou dar uso e estão desabrigados, vão ser desapropriados transformando-se em patrimônio público com finalidade de formar conjuntos habitacionais para aqueles que, de fato, tem maior dificuldade para que seus direitos sejam respeitados. Com isso, evita-se a especulação imobiliária e no momento que a propriedade é efetivamente exercida em benefício da sociedade e não apenas dos interesses de seu dono, passa a ser garantida a função social devida aos referidos imóveis.

Sendo assim, poderíamos sugerir que filmes, como o referido documentário que inspira sobre as mais diferentes formas de ocupação de

\footnotetext{
7474 Art. 182. A política de desenvolvimento urbano, executada pelo Poder Público municipal, conforme diretrizes gerais fixadas em lei, tem por objetivo ordenar o pleno desenvolvimento das funções sociais da cidade e garantir o bem- estar de seus habitantes.

$\S 4^{\circ}$ - É facultado ao Poder Público municipal, mediante lei específica para área incluída no plano diretor, exigir, nos termos da lei federal, do proprietário do solo urbano não edificado, subutilizado ou não utilizado, que promova seu adequado aproveitamento, sob pena, sucessivamente, de: I - parcelamento ou edificação compulsórios;

II - imposto sobre a propriedade predial e territorial urbana progressivo no tempo;

III - desapropriação com pagamento mediante títulos da dívida pública de emissão previamente aprovada pelo Senado Federal, com prazo de resgate de até dez anos, em parcelas anuais, iguais e sucessivas, assegurados o valor real da indenização e os juros legais.
} 
um imóvel que podem viabilizar a eficácia de direitos sociais, sejam exibidos para esse grupo que vai ser para lá alocado, com função educacional e objetiva.

Podemos perceber, no Brasil, em especial em circuitos restritos / pequenos uma crescente produção de filmes que trazem discussões jurídicas, inclusive, dentro da universidade ${ }^{75}$, que é conceituada e tem o histórico de formar profissionais excelentes.

O Rio de Janeiro recebe no Instituto Moreira Salles, em novembro de 2014, a Mostra "África Hoje" - que nesta edição homenageia NELSON MANDELA. Com curadoria da cineasta Luciana Hees, o evento exibirá 16 filmes, entre longas e médias metragens - a maioria inédito no circuito comercial, com documentários que visem ampliar a compreensão desse continente. $^{76}$

\subsection{Arte Urbana}

Muitos que compõem as classes sociais mais baixas gostariam de falar, mas não tem condições de falar, então usam da poética que tem acesso para compor o patrimônio cultural que faz parte da paisagem urbana, usada como espaço de luta

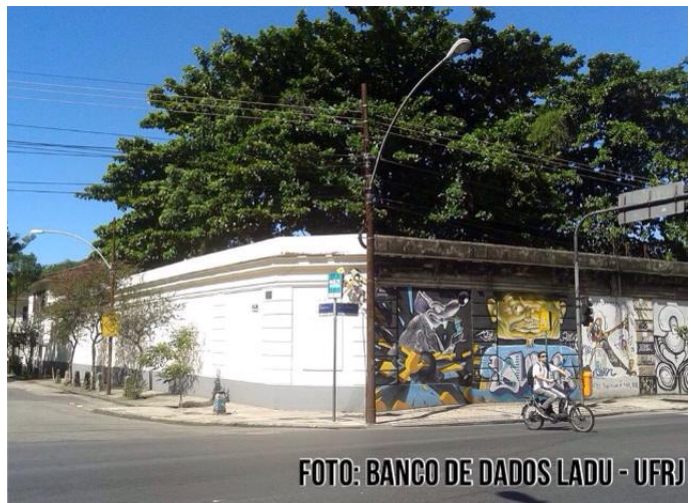
pelos direitos sociais decorrentes do Direito à Cidade.

\footnotetext{
${ }^{75}$ O Departamento de Direito da PUC-Rio, por exemplo, se utiliza da transmissão desses filmes para conscientização e informação daqueles que o assistem.

Na PUC-RIO temos exemplos tanto no Departamento de Direito, no qual a parte acadêmica responsável (CAEL) escolhe filmes ${ }^{75}$ interessantes e relevantes para formação do aluno e a faculdade considera como possibilidade de atividade complementar necessária a conclusão do curso, quanto no curso de comunicação social. No curso de comunicação social, filmes são elaborados muitas vezes com conteúdo jurídico ou sobre manifestações e lutas sociais que buscam por algum dos Direitos à Cidade.

$76 \mathrm{http} / / / \mathrm{www} . j \mathrm{jb} . c 0 m . b r / c u l t u r a / n o t i c i a s / 2014 / 11 / 02 /$ mostra-africa-hoje-comeca-terca-e-vai-ate-odia-12-no-ims/
} 
Constatados tais fatos só é reforçada a ideia de que a arte presente nos muros deve ser tombada junto ao patrimônio, de forma a proteger o

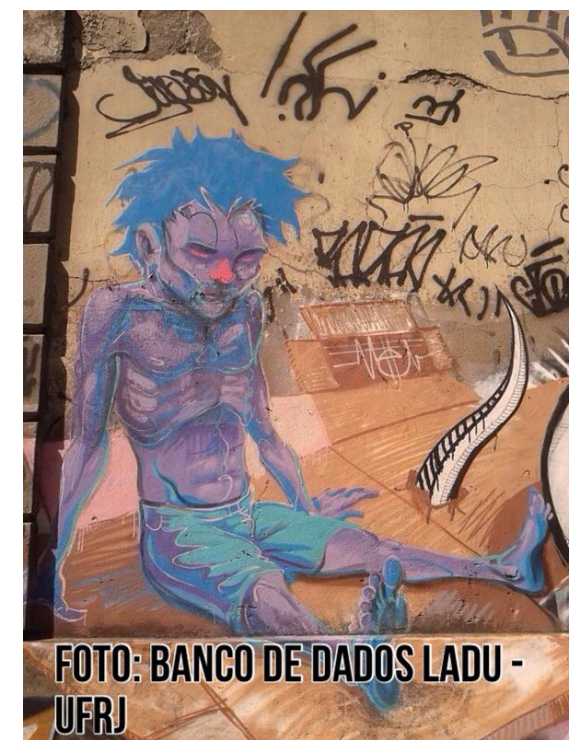
patrimônio cultural e histórico da cidade. A proteção da arte urbana é urgente e necessária pelas razões culturais, históricas e pelo reconhecimento de identidades.

No caso específico do muro do conjunto arquitetônico do hipódromo da gávea do Jockey Club brasileiro, caso referência que adotamos visto que é uma paisagem urbana tão importante e absorvida pela sociedade que estamos inseridos já, temos que considerar além dessa dimensão da arte urbana que deve ser protegida, o fato do Jockey estar situado no entorno do Jardim Botânico, criado em 1808, na cidade do Rio de Janeiro.

No ano de 2012 o Jardim Botânico, foi considerado patrimônio da humanidade através do Decreto $\mathrm{n}^{0} 35.879$ de 05 de julho de $2012^{77}$, que dispõe sobre o RIO PATRIMÔNIO DA HUMANIDADE e cria o Instituto Rio Patrimônio da Humanidade - IRPH, ratificado pela Lei 5547 de 27 de Dezembro de $2012^{78}$.Sendo assim, fica esse bem tombado, passando esse a ser protegido e ter as devidas tutelas.

Esse Decreto implica não só na sua preservação através do instrumento jurídico urbanístico do Tombamento, mas, principalmente, também a preservação do seu entorno. No caso, estamos tratando do Jockey clube que foi considerado zona de amortecimento, estabelecidas pela Lei ${ }^{\circ}$ 9.985/2000, ${ }^{79}$ analisando sua importância e suas peculiaridades, evidenciando ainda um panorama geral da gestão das unidades de

\footnotetext{
${ }^{77}$ Dispõe sobre o RIO COMO PATRIMÔNIO DA HUMANIDADE e dá outras providências.

${ }^{78}$ http://www.rio.rj.gov.br/web/irph

${ }^{79}$ Regulamenta o art. 225, § 1º, incisos I, II, III e VII da Constituição Federal, institui o Sistema Nacional de Unidades de Conservação da Natureza e dá outras providências.
} 
conservação no Brasil. O artigo $2^{\circ}$, XVIII, da Lei $n^{\circ}$ 9.985, de 18 de julho de $2000^{80}$, conceitua a zona de amortecimento (ZA), de forma simplificada, como sendo um cinturão de proteção à unidade de conservação do efeito de borda.

Partindo da Resolução CONAMA $13 / 90^{81}$, os limites da Zona de Amortecimento tiveram como ponto de partida o critério do uso de um raio de $10 \mathrm{~km}$ dos limites do Parque do Jardim Botânico em direção ao seu entorno, ajustados os limites geográficos de acordo com as características ambientais regionais e, principalmente, considerando as bacias hidrográficas e o potencial para a formação de corredores ecológicos.

Para o traçado fino da Zona de Amortecimento foram utilizados elementos geográficos e de infra-estrutura, aspectos legais (como áreas urbanas e de expansão urbana), entre outros. Os critérios de ajuste estabelecidos para a Zona de Amortecimento do PESRM é resultado dos estudos temáticos desenvolvidos no Parque e seu entorno. ${ }^{82}$

O entendimento da importância da zona de amortecimento, pra o trabalho, é de extrema relevância para que possamos entender que o conjunto arquitetônico do hipódromo da gávea do Jockey Club brasileiro, faz parte do entorno do espaço trabalhado e da área de contenção dos efeitos externos que possam de alguma maneira influenciar negativamente na conservação da unidade, compondo a área tombada ${ }^{83}$ e devendo ser protegido tanto quanto o Jardim Botânico.

\footnotetext{
${ }^{80}$ Art. $2^{\mathrm{o}}$ Para os fins previstos nesta Lei, entende-se por:

XVIII - zona de amortecimento: o entorno de uma unidade de conservação, onde as atividades humanas estão sujeitas a normas e restrições específicas, com o propósito de minimizar os impactos negativos sobre a unidade, $\mathrm{e}$

${ }^{81}$ O CONSELHO NACIONAL DO MEIO AMBIENTE - CONAMA, no uso das atribuições que lhe são conferidas pela Lei $n^{\circ} 6.938$, de 31 de agosto de 1981, alterada pela Lei $n^{\circ} 8.028$, de 12 de abril de 1990, regulamentadas pelo Decreto $\mathrm{n}^{\circ}$ 99.274, de 06 de junho de 1990, e tendo em vista o disposto em se.u Regimento Interno, e Considerando o disposto nos artigos $7^{\circ}$ e 27 , Decreto $n^{\circ}$ 99.274, de 06/06/90

Considerando a necessidade de estabelecer-se, com urgência normas referentes ao entorno das Unidades de Conservação visando a proteção dos ecossistemas ali existentes, RESOLVE:

${ }^{82} \mathrm{http}$ ://www.biodiversitas.org.br/planosdemanejo/pesrm/gestao15.htm

83 http://www.oeco.org.br/dicionario-ambiental/28754-o-que-e-uma-zona-de-amortecimento > Acesso em 10/10/2014
} 


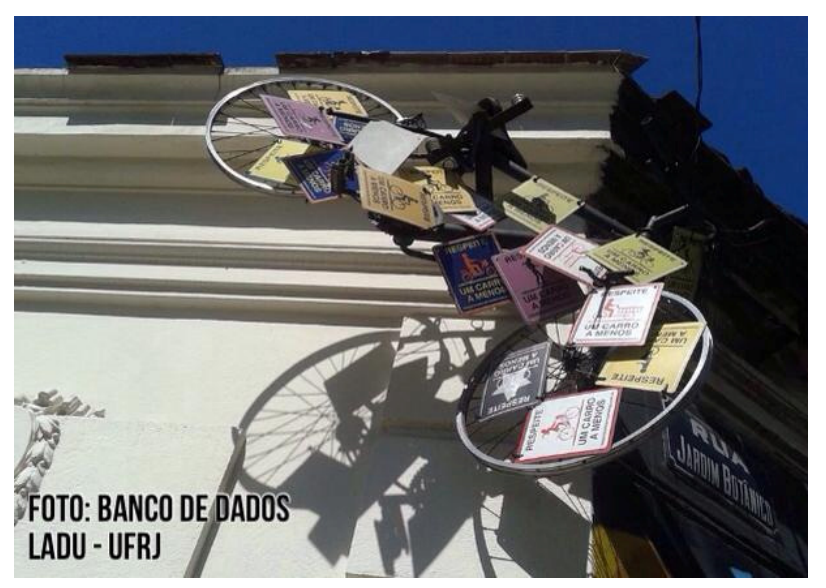

Nesse caso, o muro do Jockey deveria estar protegido, tornando-o um mural de informações. Muitas vezes a arte urbana não é usada nem como uma comunicação com o mundo, mas como um diálogo entre a própria comunidade que está envolvida em conflitos. Algo que estimule debates, pensamentos e ideias. Nesse caso, a história deixa de ser exclusivamente escrita por vencedores e passa a ter força voluntária e ser escrita por todos que participaram de um momento. ${ }^{84}$

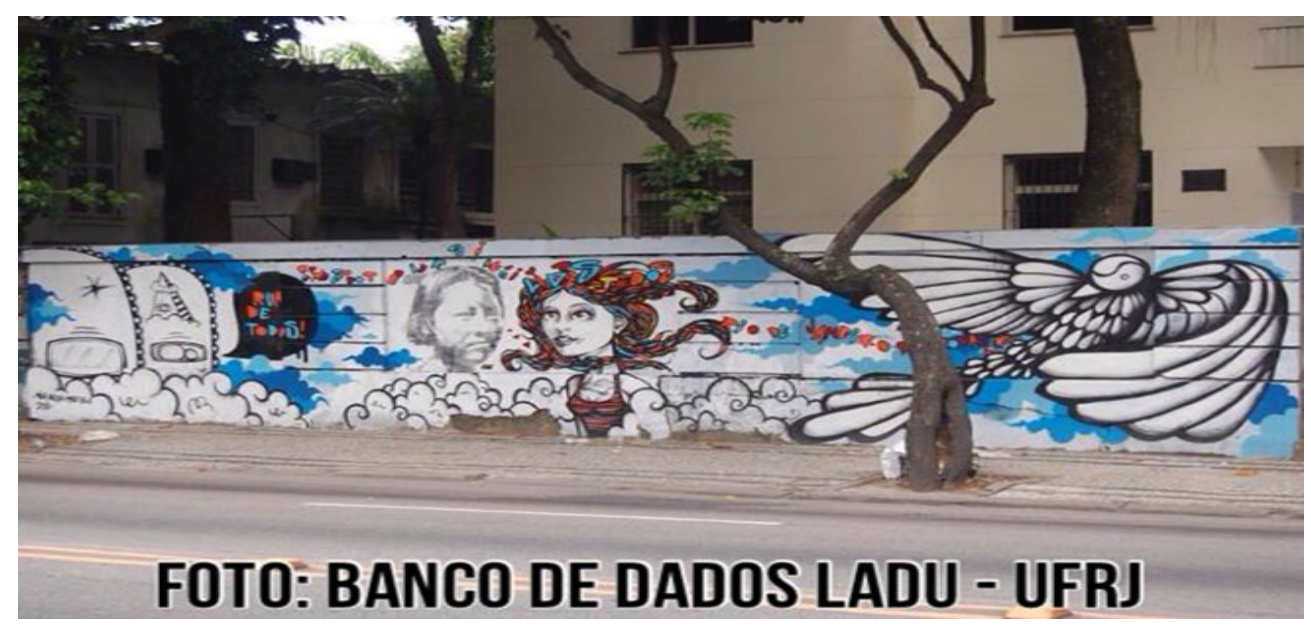

Mesmo que em diferentes formas e proporções, desde o surgimento da Arte de Rua, ela surge com caráter informativo. Com a intenção de transmitir informações, contar histórias, quebrar padrões. O objetivo dela pode ser somente conseguir atenção aos problemas sociais ou de fato afirmar pontos de vista sobre eventos históricos.

\footnotetext{
${ }^{84}$ Art of Conflict. Filme
} 


\section{Paisagem em Movimento}

A cidade constitui uma paisagem sempre em movimento, resultado das inúmeras relações sociais distintas que a compõem.

Explicações mecanicistas, de um mundo confuso e confusamente percebido, são criadas para dar base material a produção da história humana, pela qual a nossa era globalizada vive. ${ }^{85}$

Devemos considerar a existência de três mundos dentro de um, se não quisermos admitir a permanência de uma percepção enganosa, na qual todos os contextos são alargados ${ }^{86}$ para consagrar um discurso único. Milton Santos, em Por uma outra globalização - do pensamento único à consciência universal; divide eles em:

O primeiro seria o mundo tal como nos fazem vê-lo: a globalização como fábula; o segundo seria o mundo tal como ele é: a globalização como perversidade; e o terceiro, o mundo como ele pode ser: uma outra globalização. ${ }^{87}$

O mundo em que a globalização é enxergada como fábula, acaba por repetir teses não condizentes com a realidade; sem um valor cognoscitivo ${ }^{88}$ que reflita o real em sua essência, que podem acabar se tornando uma base falsamente sólida de sua interpretação. ${ }^{89}$ Nesse mundo, o culto ao consumo, por exemplo, é estimulado através de uma tese que defende o encurtamento de distâncias através de uma difusão instantânea de notícias que falsamente tornam todas as pessoas detentoras e apropriadas de uma diversidade considerável de conhecimentos, não considerando as diferenças reais existentes na formação da população mundial.

Já no mundo que o referido autor considera como mais próximo ao real, no qual a globalização é vista como perversidade, as diferenças existentes entre as classes sociais tornam-se cada vez maiores; tornando,

\footnotetext{
${ }^{85}$ SANTOS, Milton. Por uma outra globalização do pensamento único à consciência universal. p. 17

${ }^{86}$ SANTOS, Milton. A natureza do espaço, 1996.

${ }^{87}$ SANTOS, Milton. Op.cit.. p. 18

${ }^{88}$ KONDER, Leandro. Os Marxistas e a Arte. p. 28

${ }^{89}$ SANTOS, Milton. Op.cit. p. 18
} 
inclusive, os direitos sociais mais básicos cada vez mais inacessíveis aos que fazem parte das classes menos privilegiadas. Essa evolução negativa da humanidade, diretamente relacionada a instauração de uma grande competitividade, se dá pela perversidade do sistema existente hoje, que faz parte do embrião de toda essa lógica delicada e perversa. ${ }^{90}$

Há, ainda, uma terceira interpretação para globalização, mais humana, que apresenta um ideal que deveria ser alcançado. A partir de bases materiais, tais como unicidade da técnica, a convergência dos momentos e o conhecimento do planeta $^{91}$, a economia atual se apoia para formar a globalização perversa apresentada. Porém, as mesmas bases técnicas, quando interpretadas com finalidade e valor cognoscitivo, respeitando a função gnoseológica da informação de servir a fundamentos sociais, poderão servir a objetivo diverso.

Partindo das realidades e necessidades básicas de cada país, concluímos que devemos respeitar a gnoseologia, em sua máxima que defende a capacidade humana de apreender a partir da consciência, contato e experiência com o real ${ }^{92}$, e elaborar uma promessa de reformulação da própria ordem mundial ${ }^{93}$.

A paisagem urbana que compõe a cidade tornando o território parte do patrimônio cultural usado pela cidade como seu retrato dinâmico, deve respeitar, portanto, os espaços dos excluídos também constitutivo da cidade de modo a tutelar o direito dos vulneráveis. Esses ambientes sociais, dos quais desfrutam os vulneráveis tutelados, devem ser compostos pelas mais transformadoras formas e propostas e, principalmente, devem lutar por uma ordem mais humana.

\footnotetext{
90 SANTOS, Milton. Por uma outra globalização do pensamento único à consciência universal. pp. $19-20$

${ }^{91}$ Ibid. p. 20

${ }^{92}$ KONDER, Leandro. Os marxistas e a arte. p 22

93 SANTOS, Milton. Por uma outra globalização do pensamento único à consciência universal. p. 75
} 
É importante que a norma urbanística seja eficaz e aplicada para que os direitos sociais, muitas vezes não efetivos e eficazes por impossibilidades urbanísticas na cidade, possam ser garantidos em suas mais variadas instancias. Visto que estes podem se tornar exequíveis através de uma cidade mais democrática.

Considerando o diálogo entre os campos do Direito e do Urbanismo, o conceito de eficácia social da norma urbanística (priorizando os critérios da incidência, finalidade e legitimidade) foi adotado na perspectiva da análise da norma urbanística. A legitimidade foi considerada como o critério fundamental, garantindo com seu poder político a execução continuada da norma urbanística.

A importância do referido conceito foi observada principalmente no processo de análise da paisagem urbana em confronto com as normas do Estatuto da Cidade (Lei 10.257, de 2001) no que tange a paisagem urbana, uma vez que a possibilidade de transformação da paisagem e de suas formas está sempre limitada pela própria paisagem presente, e esta pode ser potencial local de permanente busca e troca de informações sobre o local que está inserido.

\subsection{Conexões na tutela jurídica: do Decreto lei $n^{\circ} 25$, de 30 de novembro de 1937 sobre Tombamento à proteção da paisagem urbana na perspectiva da eficácia social da norma urbanística}

O nosso estudo visa a proteção do direito à cidade e seus direitos sociais. Para tanto é essencial que os instrumentos jurídicos urbanísticos que tutelam o Direito a cidade venham a ser interpretados e aplicados no ambiente da cidade; ou seja, consideramos a todo momento a relevância da paisagem urbana, uma vez que na esteira de Rosângela Cavallazzi, consideramos a paisagem como um princípio de interpretação da norma 
urbanística. ${ }^{94}$ Portanto, pretendemos, a seguir, levantar respaldo normativo sobre a proteção do Patrimônio Cultural e paisagístico. A partir do Decreto lei $\mathrm{n}^{\mathrm{o}} 25$ do Tombamento até os dias atuais, situamos o estudo na cidade do Rio de Janeiro, recentemente considerada patrimônio da humanidade através do Decreto n 35879 de 05 de julho de 2012, onde dispõe sobre o RIO COMO PATRIMÔNIO DA HUMANIDADE- IRPH. ${ }^{95}$

Considerando a paisagem urbana como essencial para compreender a cidade; como forma que revela a estrutura, devendo esta ser tutelada como Patrimônio Cultural a ser protegido ${ }^{96}$, adotamos a paisagem como um princípio de interpretação da norma.

Nesta perspectiva, o reconhecimento por grupos sociais em razão da identidade, ação ou memória, é mais um fato que demonstra a necessidade dessa proteção; a necessidade de reconhecer a cultura como forte e importante referência da cidade.

Para tanto adotamos o conceito de paisagem urbana compreendido a partir dos conceitos de Cosgrove ${ }^{97}$ e Milton Santos ${ }^{98}$.

Cosgrove compreende que a paisagem é um método para se entender o mundo e as sociedades. Afirma, ainda, que a paisagem deve ser revelada como sendo decorrente de um processo, permanentemente inacabado; e, como uma forma de produzir, manipular e contemplar o espaço; como parte da "realidade."

\footnotetext{
${ }^{94}$ CAVALLAZZI , Rosângela Lunardelli . Paisagem urbana e construções normativas em projetos urbanos. Palestra na mesa sobre Projetos Urbanos e Transformações Territoriais no Rio de Janeiro no âmbito do Colóquio intitulado TRANSFORMAÇÕES TERRITORIAIS NO RIO DO SÉCULO XXI, na UERJ, com a coordenação dos professores Angela Penalva Santos (FCE), Gláucio Marafon (IGEO) e Maria Josefina Sant`Anna (IFCH) nos dias 25 e 26 de setembro de 2013.

${ }^{95}$ Ratificado pela Lei 5547 de 27 de Dezembro de 2012, como órgão estruturado no Gabinete do Prefeito.

${ }^{96}$ CAVALlAZZI, Rosangela. Perspectivas Contemporâneas Do Patrimônio Cultural: Paisagem Urbana E Tombamento.p.15

97 COSGROVE, Denis E. Social Formation and Symbolic Landscape. Wisconsin: Wisconsin Press, 1998. pp.13-14

${ }_{98}^{98}$ SANTOS, Milton. Espaço e Método. São Paulo: Nobel, 1985.

${ }^{99}$ COSGROVE, Denis E. Op.cit.
} 
A paisagem urbana, sob a ótica de Milton Santos ${ }^{100}$, reúne e associa pedaços de tempo materializados de forma diversa, autorizando comportamentos econômicos e sociais diversos. Enquanto as áreas "luminosas" são o teatro da ação dos vetores da modernidade globalizadora, as frações urbanas que "envelhecem" podem ser operadas sem maior submissão a tais nexos, escapando à regulação direta dos atores econômicos e sociais hegemônicos. ${ }^{101}$

Ao transformar a natureza, a partir da Arte, criando uma nova coisa, o homem inventa e registra sua própria história. ${ }^{102}$

$\mathrm{Na}$ atual sociedade de consumo, globalizada, a paisagem urbana tem sido capturada como mercadoria; o que constitui é um grande obstáculo na proteção do Patrimônio Cultural. A paisagem como construção, composição do mundo, é uma maneira de humanizar o meio ambiente natural e a leitura do mundo. ${ }^{103}$ A tutela jurídica sobre proteção do patrimônio no Brasil conta com importante legislação de 1937, o Decreto-lei $n^{0} 25$, que organiza a proteção do patrimônio histórico e artístico nacional. ${ }^{104}$

A paisagem urbana, quando encarada sob a lógica do processo de globalização, não só perde a identidade cultural e tem sua função social prejudicada ao negar a construção da cidade por seus moradores mediante um processo de uniformização. Sendo assim, o morador da cidade habita uma situação de vulnerabilidade a medida que tem a identidade de seu patrimônio histórico ameaçada.

Proteger o Patrimônio Cultural é manter os valores formados por grupos sociais a partir da identidade, ação e memória garantindo, então, o

\footnotetext{
100 “A paisagem é o conjunto de formas que, num dado momento, exprimem as heranças que representam as sucessivas relações localizadas entre homem e natureza. O espaço são essas formas mais a vida que os anima”. Milton Santos. Espaço e Método. São Paulo: Nobel, 1985, p. 51.

${ }^{101}$ SANTOS, Milton. A Natureza do Espaço. p. 209-210

${ }^{102}$ CAVALLAZZI, Rosangela. Perspectivas Contemporâneas Do Patrimônio Cultural: Paisagem Urbana E Tombamento

103 Ibid.

${ }^{104}$ Decreto-lei ${ }^{\circ}{ }^{25}$, de 30 de novembro de 1937. Lei do Tombamento
} 
exercício dos direitos culturais e acesso as fontes da cultura nacional; parte importante do feixe de direitos que compõe o Direito à Cidade. ${ }^{105}$

Para que os instrumentos jurídico-urbanísticos sejam explorados ao máximo e também apreendidos em todo o potencial na paisagem urbana, devemos situá-los no direito à cidade. Quando a paisagem é reconhecida na qualidade de Patrimônio Cultural, expressa um modo de viver a partir de criações artísticas e tecnológicas; estabelecendo um forte diálogo entre Direito e Urbanismo $^{106}$, pois ao criar uma mediação entre o visível e o invisível, torna uma significação simbólica fonte de sentido para toda uma coletividade.

O Brasil acompanhou a tradição Portuguesa; que já na sua Constituição (Portuguesa) de 18 de agosto de 1911, elegia como tarefa fundamental do Estado a de proteger e valorizar o patrimônio cultural do povo português. Posteriormente, a Constituição Portuguesa de 1976, que garante os direitos de fruição e patrimônio e apresenta que a valorização do patrimônio cultural, defesa e preservação devem ser ação conjunta entre Estado, cidadãos e agentes culturais. Assim como o texto da Constituição Brasileira, a Constituição Portuguesa tem evidente intenção de interferir, de projetar, de alterar, ao contrário de outros textos que têm caráter exclusivamente conservador. ${ }^{107}$

Ao se tratar da proteção da cidade, considerando esta patrimônio público, , é importante destacar o papel do Direito Público como ponto de partida para tratar o instituto do tombamento.

Agustín GORDILLO ao fazer considerações importantes a respeito da divisão do Direito em Público e Privado, chama atenção sobre a

\footnotetext{
105 Cavallazzi, Rosangela. Perspectivas Contemporâneas Do Patrimônio Cultural: Paisagem Urbana E Tombamento. pp. 10-20

106 Ibid.

107 PIRES, Maria Coeli Simões. Da proteção ao patrimônio cultural: o tombamento como principal instituto. Belo Horizonte. 1994 p. 60
} 
predominância dos interesses que afetam todo o grupo social, abordagem essencial para nossa pesquisa, sobre bem comum. ${ }^{108}$

O tombamento é um instrumento relevante na proteção do patrimônio cultural. A dinâmica social em que vivemos o alimenta com novas abordagens e interpretações, já que se relaciona com a cultura brasileira. Tombamento não é considerar uma propriedade pública ou privada de interesse social, ficando esta protegida contra a destruição, abandono ou utilização inadequada, mas também considerar suas possibilidades como instrumento jurídico urbanístico que acompanha a dinâmica da cidade. ${ }^{109}$

O Decreto lei $\mathrm{n}^{0} 25$, de 30 de novembro de 1937, da época do governo de Getúlio Vargas, para Edésio Fernandes ${ }^{110}$, é a primeira forma de materialização legislativa do princípio constitucional da função social da propriedade, já reconhecido anteriormente pela Constituição Federal de $1934^{111}$. Dispõe o Decreto sobre este Instituto com objetivo de regulamentálo, e a partir daquele ano outras legislações a respeito da matéria surgem.

\section{O Art. $4^{\circ}$ do DECRETO-LEI N ${ }^{\circ}$ 25, DE 30 DE NOVEMBRO DE} 1937, que organiza a proteção do patrimônio histórico e artístico nacional, apresenta os 4 Livros do Tombo em seus incisos, nos quais os bens tombados estarão registrados, classificados segundo sua natureza nos quatro livros do Tombo:

\footnotetext{
${ }^{108}$ Fábio Konder Comparato define o bem comum do povo como algo que está acima de qualquer interesse particular, seja de classe, igreja, sindicato, partido político. Toda vez que um direito particular entre em conflito com o bem comum do povo, ele tem de ser posto de lado. http://www.ipea.gov.br/desafios/index.php?index_php?option=com_content\&view=article \&id=25 80\%3Acatid\%3D28\&Itemid $=23 \&$ option $=$ com_content $>>$ acesso em: $10 / 10 / 2014$

${ }^{109}$ CAVALLAZZI Rosangela. Perspectivas Contemporâneas Do Patrimônio Cultural: Paisagem Urbana E Tombamento. pp. 20-30

${ }^{110}$ Em seus comentários à Constituição de 1967 (EC/69) o prof. José Celso de Mello Filho afirmava que o tombamento “(...) É o meio posto à disposição do Poder Público para efetiva tutela do patrimônio cultural e natural do País. É por meio do tombamento que o Poder Público cumpre a obrigação constitucional de proteger os documentos, as obras e os locais de valor histórico ou artístico, os monumentos e paisagens naturais notáveis, vem como as jazidas arqueológicas." Deve-se destacar, ainda, que o art. 216, CF, explicita várias formas pelas quais o poder público protegerá o patrimônio cultural, não sendo o tombamento o único instrumento legal de preservação. In: José C. Mello Filho, Const. Federal Anotada, p. 538.

${ }^{111}$ FERNANDES, Edésio. ALFONSIN, Betânia. Revisitando o Instituto do tombamento. Bela Horizonte: Fórum, 2010.
} 
1) no Livro do Tombo Arqueológico, Etnográfico e Paisagístico, as coisas pertencentes às categorias de arte arqueológica, etnográfica, ameríndia e popular, e bem assim as mencionadas no $\S 2^{\circ}$ do citado art. $1^{\circ}$.

2) no Livro do Tombo Histórico, as coisas de interêsse histórico e as obras de arte histórica;

3) no Livro do Tombo das Belas Artes, as coisas de arte erudita, nacional ou estrangeira;

4) no Livro do Tombo das Artes Aplicadas, as obras que se incluírem na categoria das artes aplicadas, nacionais ou estrangeiras. ${ }^{112}$

A partir de cada bem tombado, há uma breve sistematização de informações constantes nos Livros do Tombo. Os campos destinados às caracterizações dos bens culturais podem estar preenchidos na sua totalidade ou não, dependendo de cada caso. Suas ações voltadas à identificação, documentação, restauração, conservação, preservação, fiscalização e difusão, estão calcadas em legislações específicas sobre cada um dos temas pertinentes ao seu universo de atuação. Todos os entes federativos tem competência para tombar, ou seja, realizar a inscrição do bem num livro do tombo visando a proteção do patrimônio cultural brasileiro. ${ }^{113}$ Art. 134. O Tombamento se dará conforme estabelecido na Lei Municipal $n^{\circ}$ 166, de 27 de maio de 1980.

Tendo em vista a necessária proteção dos Patrimônios histórico, cultural e paisagístico, o Decreto de 1937 deve ser interpretado à luz da Constituição Federal de 1988, que determina a proteção do patrimônio cultural. Nesta perspectiva, de acordo com o artigo 216 , parágrafo $1^{\circ}$ da Constituição, o Estado, tem a obrigação, juntamente com a sociedade, de manter os meios de acautelamento e preservação, para proteger o patrimônio cultural brasileiro, com fundamental respaldo para proteção além do patrimônio histórico, do paisagístico e artístico.

Segundo o texto constitucional temos:

Art. 216. Constituem patrimônio cultural brasileiro os bens de natureza material e imaterial, tomados individualmente ou em conjunto, portadores de referência à identidade, à ação, à memória dos diferentes grupos formadores da sociedade brasileira, nos quais se incluem:

I - as formas de expressão;

II - os modos de criar, fazer e viver;

III - as criações científicas, artísticas e tecnológicas;

IV - as obras, objetos, documentos, edificações e demais espaços destinados às manifestações artístico-culturais;

112 DECRETO-LEI No 25, DE 30 DE NOVEMBRO DE 1937

${ }^{113}$ Disponível em: http://portal.iphan.gov.br/. Acesso em 11 de out 2014. 
V - os conjuntos urbanos e sítios de valor histórico, paisagístico, artístico, arqueológico, paleontológico, ecológico e científico.

O referido artigo define a incidência da proteção do Patrimônio Cultural, mas sua interpretação se torna de fato eficaz quando combinada ao artigo $215^{114}$, da mesma Constituição, que determina que o Estado deve garantir a todos o pleno exercício dos direitos culturais e acesso às fontes da cultura nacional. ${ }^{115}$

O texto constitucional referido define o que é o patrimônio cultural brasileiro que deve ser protegido e determina, ainda, que a proteção à cultura é não só um direito do cidadão, mas um dever do Estado que é formador e determinante dos sentimentos de ação e cidadania. O texto constitucional faz referencia, ainda, a preservação cultural nos arts. 23 e 24, nos quais estabelece as competências legislativa e executiva.

Registramos a seguir alguns autores brasileiros, que estudam o Instituto do Tombamento, e o definem de diferentes formas.

Jose Afonso da Silva define como "o ato do poder público que, reconhecendo o valor cultural (histórico, arqueológico, etnográfico, artístico ou paisagístico) de um bem, mediante sua inscrição no livro próprio,

\footnotetext{
${ }^{114}$ Art. 215. O Estado garantirá a todos o pleno exercício dos direitos culturais e acesso às fontes da cultura nacional, e apoiará e incentivará a valorização e a difusão das manifestações culturais. $\S 1^{\circ}$ - O Estado protegerá as manifestações das culturas populares, indígenas e afro-brasileiras, e das de outros grupos participantes do processo civilizatório nacional.

$\S 2^{\circ}$ - A lei disporá sobre a fixação de datas comemorativas de alta significação para os diferentes segmentos étnicos nacionais.

$\S 3^{\circ}$ A lei estabelecerá o Plano Nacional de Cultura, de duração plurianual, visando ao desenvolvimento cultural do País e à integração das ações do poder público que conduzem à: (Incluído pela Emenda Constitucional n ${ }^{\circ} 48$, de 2005)

I defesa e valorização do patrimônio cultural brasileiro; (Incluído pela Emenda Constitucional $\mathrm{n}^{\circ}$ $\underline{48, \text { de 2005) }}$

II produção, promoção e difusão de bens culturais; (Incluído pela Emenda Constitucional n ${ }^{\circ} 48$, de 2005)

III formação de pessoal qualificado para a gestão da cultura em suas múltiplas dimensões; (Incluído pela Emenda Constitucional n ${ }^{\circ} 48$, de 2005)

IV democratização do acesso aos bens de cultura; (Incluído pela Emenda Constitucional n ${ }^{\circ} 48$, de $\underline{2005)}$

$\mathrm{V}$ valorização da diversidade étnica e regional. (Incluído pela Emenda Constitucional no 48 , de $\underline{2005)}$

${ }^{115}$ CAVALLAZZI, Rosangela. Perspectivas Contemporâneas Do Patrimônio Cultural: Paisagem Urbana E Tombamento.
} 
subordina-o a um regime jurídico especial que lhe impõe vínculos de destinação, de imodificabilidade e de relativa inalienabilidade." 116

Tombamento, segundo Antônio A. de Queiroz Telles, é o mesmo que colocar sob o abrigo e a tutela pública os bens que pelas suas características históricas, artísticas, naturais e arqueológicas, mereçam integrar o patrimônio cultural do país. ${ }^{117}$

Maria Sylvia Zanella di Pietro afirma que Tombamento é a forma de intervenção do Estado na propriedade privada, que tem por objetivo a proteção do patrimônio histórico e artístico nacional, assim considerado, pela legislação ordinária. ${ }^{118}$

Diógenes Gasparino, sem adentrar na natureza jurídica do tombamento, define como sendo a submissão de certo bem, público ou particular, a um regime especial de uso, gozo, disposição ou destruição em razão de seu valor histórico, paisagístico, arqueológico, científico ou cultural. $^{119}$

Segundo Nathalia Arruda Guimarães, "o tombamento gera, além de uma nova configuração para propriedade sobre a qual recai, também limitações sobre as propriedades vizinhas. É o que a doutrina chama de efeito reflexo, quando então os limites se estendem a terceiros." (p. 225)

A autora assume o desafio de responder o que significa hoje a visibilidade do bem cultural, o que implica em identificar ou determinar a dimensão das restrições impostas as novas construções vizinhas na perspectiva da preservação do bem tutelado "que não prejudique a visão do bem tutelado" ${ }^{\prime 20}$.

\footnotetext{
${ }_{117}^{116}$ SILVA, José Afonso da. Ordenação constitucional da cultura. 2001, p. 159.

117 TELLES, Antônio A. de Queiroz. Tombamento e seu Regime Jurídico. Editora Revista dos Tribunais, 1992. p.13

${ }_{118}$ PIETRO, Maria Sylvia Zanella di. Direito Administrativo, p. 131.

${ }^{119}$ GASPARINI, Diógenes. Direito administrativo, p. 451

${ }^{120}$ GUIMARÃES, Nathalia. O Tombamento de Bens Imóveis - Apontamentos sobre o Sentido e os Valores do Tombamento de Bens Imóveis na Atualidade e a Proteção do Entorno via Legislação Especial e Urbanística. Uma abordagem Comparada da Legislação Brasileira e da Portuguesap. 216
} 
Portanto os conceitos ressaltam a forma de intervenção do Estado na propriedade visando a tutela pública dos bens, mas para a nossa pesquisa, considerando o caso-referência do "muro do Jockey" , o conceito de Nathalia Guimarães é o mais relevante pois chama atenção para o entorno do bem tombado.

O entorno do bem cultural tombamento também esta adstrito a limitações no que tange ao direito do proprietário. A proteção do entorno implica na obrigação de terceiros de se absterem do risco de prejudicar a integridade do bem cultural.

Lembra a referida autora que a natureza jurídica das obrigações do proprietário do entorno do bem tombado está diretamente relacionado a servidão gerada pelo tombamento em relação a terceiros proprietários das construções vizinhas do bem cultural. ${ }^{121}$

No caso da cidade do Rio de Janeiro, o seu Plano Diretor, a Lei complementar $n^{\circ} 111$ de $1^{\circ}$ de fevereiro de 2011, dispõe sobre a Política Urbana e Ambiental do Município e instituindo o Plano Diretor de Desenvolvimento Urbano Sustentável do Município do Rio de Janeiro e dá outras providências.

Em seu texto, o artigo 132, dispõe sobre o entorno do patrimônio cultural tombado:

São instrumentos básicos para proteção do patrimônio cultural, além de outros previstos nesta Lei Complementar e na legislação federal, estadual e municipal:

I. o Tombamento e a instituição de Área de Entorno do Bem Tombado; Do Tombamento e das Áreas de Entorno de Bem Tombado

O tombamento é uma estratégia de salvaguarda dos bens culturais.

\footnotetext{
${ }^{121}$ GUIMARÃES, Nathalia. O Tombamento de Bens Imóveis - Apontamentos sobre o Sentido e os Valores do Tombamento de Bens Imóveis na Atualidade e a Proteção do Entorno via Legislação Especial e Urbanística. Uma abordagem Comparada da Legislação Brasileira e da Portuguesa, p. 225
} 
Segundo Nathália Arruda Guimarães, o efeito imediato do Tombamento é a servidão administrativa dos bens vizinhos ou da vizinhança ${ }^{122}$. O art. 18, decreto lei 25/1937, disciplina essa servidão.

Art. 18. Sem prévia autorização do Serviço do Patrimônio Histórico e Artístico Nacional, não se poderá, na vizinhança da coisa tombada, fazer construção que lhe impeça ou reduza a visibílidade, nem nela colocar anúncios ou cartazes, sob pena de ser mandada destruir a obra ou retirar o objéto, impondo-se nêste caso a multa de cincoenta por cento do valor do mesmo objéto.

Para isso, devem ser considerados os efeitos suportados por terceiros (efeito reflexo), proprietários do entorno do bem cultural, considerando, ainda, a presença do Estatuto da Cidade.

O tombamento impõe restrições e a servidão deve ser encarada como uma restrição real.

Ainda refletindo sobre o Art. $18^{123}$, previamente citado, ressaltamos que o entorno deve ser entendido como ambiente do monumento. Tornando-se o entorno parte do Patrimônio Cultural e Histórico, quando ele absorve características daquele local e das pessoas que ali vivem, deve ser protegido juntamente ao bem.

Na doutrina italiana do conceituado o arquiteto Giovannoni afirma que não deve se limitar a considerar o monumento singular, mas estender o conceito de conservação ao ambiente circunstante, sendo necessária sua proteção por sua decisiva influência na valorização. ${ }^{124}$

Gordillo destaca o princípio da defesa (o direito dos indivíduos e grupos de serem ouvidos, de produzirem provas e controlar a produzida

\footnotetext{
${ }^{122}$ Guimarães, Nathalia. O Tombamento de Bens Imóveis - Apontamentos sobre o Sentido e os Valores do Tombamento de Bens Imóveis na Atualidade e a Proteção do Entorno via Legislação Especial e Urbanística. Uma abordagem Comparada da Legislação Brasileira e da Portuguesa ,p. 226

${ }^{123}$ Art. 18. Sem prévia autorização do Serviço do Patrimônio Histórico e Artístico Nacional, não se poderá, na vizinhança da coisa tombada, fazer construção que lhe impeça ou reduza a visibílidade, nem nela colocar anúncios ou cartazes, sob pena de ser mandada destruir a obra ou retirar o objéto, impondo-se nêste caso a multa de cincoenta por cento do valor do mesmo objéto.

${ }^{124}$ GUIMARÃES, Nathalia. O Tombamento de Bens Imóveis - Apontamentoss sobre o Sentido e os Valores do Tombamento de Bens Imóveis na Atualidade e a Proteção do Entorno via Legislação Especial e Urbanística. Uma abordagem Comparada da Legislação Brasileira e da Portuguesa
} 
pela administração pública) como critério de eficácia política e de legitimidade de exercício do poder. ${ }^{125}$ Sendo assim, a forma como esses grupos encontraram para se expressar e se fazerem ouvidos não deve ser apagada ou desconsiderada como parte do patrimônio cultural ou de relevante representação social. ${ }^{126}$

Defende como característica fundamental do processo administrativo, a sua objetividade, que protege não apenas o interessado ou a determinação de seus direitos, mas defende igualmente a norma jurídica objetiva, com o fim de manter a legalidade e a ideia de justiça no funcionamento administrativo.

A administração pública tem o dever de atender ao interesse público

Observamos os autores do Direito Administrativo, ao considerarem o tombamento como limitação ao direito de propriedade, afirmam que as limitações alcançariam o exercício de suas faculdades. Entretanto, a partir da Constituição de 1988, o princípio da função social da propriedade pública e privada atinge não só o exercício das faculdades do proprietário, mas essencialmente o próprio conteúdo da propriedade. Portanto a interpretação da tutela do patrimônio a partir do instituto do tombamento deve considerar também as obrigações. O princípio cardeal do processo administrativo, como de qualquer procedimento de exercício do poder sobre um indivíduo ou grupo de indivíduos é o devido processo, o procedimento leal e justo, afirma Gordillo. Este princípio é óbvio quando se trata do processo judicial - também deveria sê-lo no processo administrativo. ${ }^{127}$

Ouvir o interessado e o público antes de decidir algo que os afeta não é apenas um princípio de justiça, é igualmente um critério de eficácia política e administrativa, até de boas relações públicas, um dever ético - um governo preocupado com a sua imagem na opinião pública e com seus

\footnotetext{
125 GORDILLO, Agustín. Tratado de Derecho Administrativo. 5.ed. Buenos Aires: Fundación de Derecho Administrativo, 2000. tomo II. p. IX-15-16.

${ }^{126}$ Ibid. p. IX-35.

${ }^{127}$ Ibid. p. IX-13.
} 
eleitores agiria bem ao não privá-los da audiência prévia à decisão. A audiência dos interessados assegura um melhor conhecimento dos fatos e contribui para uma melhor administração e uma mais justa decisão a um menor custo político. O princípio é necessário mesmo quando se cuida de fatos absolutamente claros, cuja prova seja contundente e unívoca, porque a administração pública leva em consideração para sua decisão não somente razões de legitimidade, mas também de oportunidade e conveniência motivo pelo qual a voz dos potenciais afetados aporta relevantes elementos de juízo e sinaliza o grau de satisfação do interesse público comprometido. $^{128}$

Expõe o referido autor, ainda, que se nos dias atuais a democracia não é apenas uma maneira de se chegar ao poder, mas também uma forma de exercê-lo, obviamente num Estado de Direito o poder não pode se manifestar juridicamente de modo unilateral, sem prévia oportunidade de debate.

Logo, observamos no caso-referência do muro do Jockey que o Estado deve escutar e analisar a argumentação que representa a voz da sociedade para decidir sobre o tombamento desse bem, para que a decisão do poder público não implique e corrobore com o apagar da história que o bem carrega ao longo de tantos anos

A doutrina brasileira debate sobre o momento em que incide a ação real a servidão ao bem vizinho. Embora a lei não determine, a doutrina tem entendido que ocorre a partir da averbação do instituto no registro de imóveis.

Porém, Nathalia Guimarães ${ }^{129}$ é mais estrita e considera que desde a abertura do processo administrativo do tombamento já devem ser aplicadas as restrições aos proprietários dos bens do entorno, vizinhos ao bem tombado.

\footnotetext{
128 Disponível em: http://www.editoraforum.com.br/ef/index.php/conteudorevista/?conteudo=46701\#ref9. Acesso em 08 de out 2014.

${ }^{129}$ GUIMARÃES, Nathalia. Revisitando o Instituto do Tombamento p. 230.
} 
No caso referencia estudado, consideramos que esse momento sem duvida deve coincidir com a data que o Jardim Botânico foi considerado Patrimônio da Humanidade e que, por consequência, foi considerado zona de amortecimento, conforme observamos em capítulo anterior, como sendo cinturão de proteção à unidade de conservação do efeito de borda.

Sobre a visibilidade da coisa tombada, ou seja, fruição estética, consideramos que o entorno acaba por fazer parte e compor esse patrimônio. Porém, as características de harmonia, interação e ambiência devem ser encarados não só do ponto de vista físico, mas também finalístico. Não é só a beleza dos muros que está em questão, a parte física, mas a finalidade daquelas manifestações artísticas, que expressam algo com a finalidade que alguém veja a Arte manifestada.

Entendemos o tombamento dos Bens Culturais como a proteção especial dos bens culturais. A tutela dos bens culturais assenta-se no reconhecimento de seu valor histórico, arqueológico, artístico ou paisagístico pelos Órgãos competentes.

Ao longo de muitos anos, no Brasil, somente protegeram e restauraram os monumentos mais importantes, sem perceber que estes podem perder muito de seu caráter quando seu enquadramento é alterado. Por isso, concluiu-se necessária proteção desses conjuntos que se integrem na paisagem para valorização da envolvente.

O tombamento é reconhecido como um instrumento de gestão da cidade.

O tombamento, porém, não deve ser observado só como um instrumento de gestão da cidade, mas como tendo implícito o seu potencial para proteção do patrimônio cultural e dos bens culturais. Os conjuntos culturais onde acontecem as manifestações humanas de diversas naturezas devem estar protegidos. 
A Arte e o Direito devem ser entendidos como modo de articular os instrumentos processuais de proteção com a arte e cultura. ${ }^{130}$

Percebe-se, ainda, a relevância da abordagem interdisciplinar no sentido da compreensão e reconhecimento da paisagem, sob a forma de arte urbana (grafites, instalações, intervenções). Os instrumentos jurídicos que protegem o patrimônio histórico, cultural e paisagístico devem considerar a dinâmica da paisagem urbana, ou seja, a paisagem em movimento.

Logo a importância das Cartas das da Paisagem.

Neste sentido o conteúdo da Carta Europeia do Patrimônio Arquitetônico $^{131}$ pode ser importante para interpretação das normas urbanísticas federal do tombamento no Brasil.

A Portaria $n^{\circ} 127$, de 30 de abril de 2009, divulgada pelo Instituto do Patrimônio Histórico e Artístico Nacional (IPHAN), estabelece a chancela da Paisagem Cultural. ${ }^{132}$ O Capítulo III, DA EFICÁCIA, em seu artigo $3^{\circ}$ apresenta que:

"A chancela da Paisagem Cultural Brasileira considera o caráter dinâmico da cultura e da ação humana sobre as porções do território a que se aplica, convive com as transformações inerentes ao desenvolvimento econômico e social sustentáveis e valoriza a motivação responsável pela preservação do patrimônio."

No Brasil merece destaque a Portaria ${ }^{\circ}$ 127, de 30 de abril de 2009, divulgada pelo Instituto do Patrimônio Histórico e Artístico Nacional (IPHAN), estabelece a chancela da Paisagem Cultural. ${ }^{133}$ O Capítulo III, DA EFICÁCIA, em seu artigo $3^{\circ}$ apresenta que:

"A chancela da Paisagem Cultural Brasileira considera o caráter dinâmico da cultura e da ação humana sobre as porções do território a que se aplica, convive com as transformações inerentes ao desenvolvimento econômico e social sustentáveis e valoriza a motivação responsável pela preservação do patrimônio."

\footnotetext{
${ }^{130}$ Ação popular (lei 4717/65 de 29 de junho), ação civil pública (lei 7347/85)

${ }^{131}$ CARTA EUROPEIA DO PATRIMÓNIO ARQUITECTÓNICO. Amsterdã, Outubro de 1975 .

${ }^{132}$ Portaria $\mathrm{n}^{\mathrm{o}} 127$, de 30 de abril de 2009. Estabelece a chancela da Paisagem Cultural Brasileira

133133 Portaria $\mathrm{n}^{\mathbf{o}}$ 127, de 30 de abril de 2009. Estabelece a chancela da Paisagem Cultural Brasileira
} 
Recentemente, em 2012 realizou um importante debate ${ }^{134}$ sobre os princípios da Carta da Paisagem, apresentados pela ABAP - Associação Brasileira de Arquitetos Paisagistas. A referida carta em sua introdução afirma sobre o que é uma carta da paisagem:

'Uma Carta da Paisagem é uma declaração de princípios éticos ( que envolvem a ecologia, a justiça social e as políticas culturais e econômicas de desenvolvimento) para promover o reconhecimento, avaliação, proteção, gestão e planejamento sustentável de paisagens em cada país, através da adoção de convenções (leis, acordos) que reconhecem a diversidade paisagística e os valores locais, regionais e nacionais, bem como os princípios e processos relevantes para salvaguardar os recursos da paisagem." 135

Partindo do caso referencia do tombamento do conjunto arquitetônico do Hipódromo da Gávea do Jockey Club brasileiro, e a partir de uma análise à luz do Estatuto da Cidade e do Plano Diretor da Cidade do Rio de Janeiro, conclui-se que o Direito à Cidade tem que estar garantido para além da proteção aos muros. O caso referencia permite demonstrar a importância dessa atualização dos conceitos de tombamento para proteção da paisagem. O Estatuto da cidade assume esse instrumento como meio para tornar eficaz o direito à cidade, que engloba o conceito de qualidade de vida e de bens culturais.

A voz dos potenciais afetados responsáveis pela interferência urbana representada no contorno da cidade do Rio de Janeiro destaca importantes elementos de juízo e demonstra o interesse público, que é de grande importância para o caso.

Como diz o poeta Pereira Lima, em seu texto Grafitos: uma nova forma de folclore? :

"Se os gestos, pregões, xingamentos, (...), etc., são considerados sabedoria popular, isto é, Folclore, por que não os grafitos - o que o povo escreve ou

\footnotetext{
${ }^{134}$ Vide Oficina Carta da Paisagem realizada auditório do IPHAN-Rio, nos dias 9 e 10 de junho de 2012, promovida pelo PROURB-FAU/UFRJ, com a coordenação de Lucia Sá Costa e em cooperação com a $\mathrm{ABAP}$, com o objetivo de promover um debate sobre o aprofundamento dos doze princípios da Carta Brasileira da Paisagem .

${ }^{135}$ Vide anexo ao trabalho a copia da Carta Brasileira da Paisagem
} 
rabisca nos muros, ora por sua veia cômica, ora extravasamento de revolta pelas opressões que há tantos milênios sofrem?

O homem pré-histórico preso dias ou meses em suas cavernas pelas tempestades ou nevascas cataclísmicas não foi levado também - mais que pelo misticismo ou magia - a passar o tempo rabiscando nas paredes das grutas? (...)

Meditemos sobre dois fatos incontestáveis: a) o Folclore é a sabedoria popular; e b) o povo - que sempre participou ou criou essa sabedoria - em todos os momentos da história foi sempre o oprimido ou o menos privilegiado, ou o que menos partilhou de riqueza, ou a parte menos culta nas nações, justificando a própria definição do Folclore.

Duas consequências decorrem: a) o povo de todas as épocas esteve sempre revoltado com as desigualdades sociais; e b) sempre sob censura ou mordaça, raramente foi livre para externar suas queixas, e até mesmo seu riso, que podia ser tomado como zombaria. Então, ele, protegido pelo anonimato e a solidão, nas noites desertas ou a sós nas latrinas, extravasa o que lhe vem há tanto recalcado.

Que estudo fabuloso de psicologia coletiva, de filosofia política ou sociologia, daria uma pesquisa sobre todos os grafitos que andam pelo mundo, desde os rabiscos nas grutas primitivas, nas selvas, até as frases obcenas ou de crítica, nas paredes das casas de Pompéia, nas catacumbas romanas, nos "subways", nos monumentos, nos muros, nas latrinas, onde, estando sempre a sós e esperando sem nada a fazer a não ser sua função fisiológica, o Homem demonstre o que lhe vem na alma?"136

A partir de análise de casos-referência é possível observar melhor a presença de uma disputa de espaços físicos e simbólicos no contexto da cidade do Rio de Janeiro indicando a relevância do papel do poder público no processo de tutela da paisagem urbana com necessária proteção jurídica.

Deve-se observar, então, que se junto ao surgimento dessa forma de arte no mundo, ela aparece e é representada em parte de nosso patrimônio ao longo de anos; passa a mesma a fazer parte do patrimônio cultural integrando e devendo fazer parte da tutela jurídica, uma vez que expõe questões presentes em nosso núcleo social e busca recuperar o espaço democrático

\subsection{Arte e direito na paisagem urbana: Arte no processo de conscientização e exercício dos direitos sociais que constituem o direito à cidade}

\footnotetext{
${ }^{136}$ PEREIRA, Lima. Grafitos: uma nova forma de folclore?
} 
A partir da fundamentação observada nos capítulos anteriores, priorizamos a tutela jurídica para a proteção da paisagem urbana mediante a eficácia social da norma urbanística, considerando a Arte no processo de conscientização e exercício dos direitos sociais que constituem o direito à cidade.

Considerando a cultura não somente como forma de erudição, no sentido dos grandes clássicos literários e grandes pintores, e sim a partir da cidade construída por seus moradores, protegendo a paisagem existente.

O IPHAN registra, dentre suas Cartas Patrimoniais, a declaração do México em Conferência Mundial sobre as Políticas Culturais, em 1985:

"O patrimônio cultural de um povo compreende as obras de seus artistas, arquitetos, músicos, escritores e sábios, assim como as criações anônimas surgidas da alma popular e o conjunto de valores que dão sentido à vida. Ou seja, as obras materiais e não materiais que expressam a criatividade desse povo: a língua, os ritos, as crenças, os lugares e monumentos históricos, a cultura, as obras de arte e os arquivos e bibliotecas. Qualquer povo tem o direito e o dever de defender e preservar o patrimônio cultural, já que as sociedades se reconhecem a si mesmas através dos valores em que encontram fontes de inspiração criadora. (...) A preservação e o apreço do patrimônio cultural permitem, portanto, aos povos, defender a sua soberania e independência e, por conseguinte, afirmar e promover sua identidade cultural."

(Declaração do México, Conferência Mundial sobre as Políticas Culturais, México, 1985, ICOMOS- Conselho Internacional de Monumentos e Sítios). ${ }^{137}$

Muito próximo a discussão em tela, observamos desde 1985 um pensamento próximo ao que temos hoje. Fica, então, a paisagem urbana responsável por receptar e compor o patrimônio cultural, tornando possível a eficácia dos direitos sociais que constituem o Direito à Cidade.

Devem ser considerados essencialmente os direitos essenciais à educação, ao lazer e à preservação do Patrimônio Cultural, histórico e paisagístico principalmente, quando se trata do feixe de direitos do Direito à Cidade.

Os diversos exemplos práticos e casos referência que foram apresentados demonstraram que a Arte desempenha um papel muito

137 IPHAN. Cartas patrimoniais. Rio de Janeiro: 1995. (Caderno de Documentos, 3) 
importante no processo de conscientização para o efetivo exercício dos direitos sociais que constituem o direito à cidade.

O muro do Jockey, que há muitos anos recepta pinturas em sua maioria em forma de grafites e pichação, torna Arte mensagens acessíveis a todos, constituindo assim parte do patrimônio cultural ao transmitir informações, além de representar parte da história local.

O caso-referência adotado na arte urbana exemplifica uma dualidade no Instituto do Tombamento gerada a partir da proteção dos muros do Jockey.

Não há mais que se questionar o fato de que a arte urbana presente nos muros integra ou não o patrimônio cultural daquela área, ela deve ser protegida pelo Instituto do Tombamento interpretado à luz da Constituição federal de 1988.

Caso contrário, quando a arte já está inscrita na paisagem será um verdadeiro contrassenso apagar a história que ali está sendo representada e contada pelos habitantes daquele lugar.

Para o estudo do Tombamento a valorização do patrimônio cultural tem sido essencial, pois permite reconhecer sua capacidade de representar e interpretar vivências, memória, identidades.

No caso do Teatro e sua relação com o exercício dos direitos sociais que compõem o direito à cidade fica mais visível no momento que a forma de teatro trabalhada foge a estética usada pela classe dominante, que não é compreendida por todos, além de não necessariamente ter um caráter político, passando a representar assim a estética do Oprimido. Essa forma de trabalho busca que sejam retomadas as próprias palavras, imagens e sons desses grupos ${ }^{138}$, que ao se sentirem representados, de fato, podem entender, comunicar e expressar a realidade que vivem. A ideia dessa forma de Teatro não é a de vender uma técnica, mas a de instrumentalizar essas

\footnotetext{
${ }^{138}$ BOAL, Augusto. Teatro do Oprimido. p.49
} 
pessoas para que elas possam colaborar com a evolução e melhoria ${ }^{139}$ dentro da paisagem urbana que estão inseridas.

Já no cinema, a proposta por filmes mais informativos ou aperfeiçoamento e solidificação de conceitos que já se fazem presentes na realidade também pode ser transformador.

Observamos, então, como sendo de grande relevância para a instrução e informação de grupos, a edição de filmes de qualidade e com conteúdo controlado e de acordo com a realidade jurídica vivida. $\mathrm{O}$ cinema conscientiza e participa do processo que torna os indivíduos realmente sujeitos de direito que tem a capacidade de reconhecer e tornar seus direitos sociais violados exequíveis. Para isso, o conteúdo jurídico deve estar de acordo com a legislação vigente e traduzido em uma linguagem acessível a todos.

Dessa forma, consideramos a Arte, em suas variadas formas, como importante elemento fazendo parte da paisagem urbana, assim com forte papel que ao conscientizar potencializa o exercício dos direitos sociais que constituem o direito à cidade.

${ }^{139}$ BOAL, Augusto. Teatro do Oprimido. pp.51-72 


\section{Conclusão}

A complexidade do tema exigiu o estudo segundo uma abordagem interdisciplinar, privilegiando a relação entre Direito e Arte, mediante os exemplos do Teatro, do Cinema e da Arte urbana.

A partir do entendimento da cidade, de suas vulnerabilidades e desafios e entendidas as funções sociais da cidade, observamos que a Arte pode ter grande influencia e poder transformador sobre a mesma, na medida em que interfere na busca por direitos.

Assim os conflitos urbanos e desafios das cidades contemporâneas, foram estudados na dimensão do desenvolvimento urbano e da identidade da população com patrimônio cultural tutelado, levando-se em conta a necessidade de gestão democrática em todo o processo de construção da política urbana.

Percebemos que a forma jurídica pode ser um obstáculo ou uma possibilidade na tutela da paisagem urbana, como patrimônio cultural a ser protegido. Ficando certo que a proteção da paisagem da cidade é a melhor forma de preservar identidade e características que sejam de maior relevância e influência para o local e a sociedade.

Podemos entender o quão eficaz e necessário pode ser um plano artístico de conscientização, a partir do momento que a arte passa a ser respeitada, e torna acessível a todas as classes essa forma de transmissão de informações indispensáveis ao saber, que atendam ao interesse público.

Concordamos com a ideia marxista de que o que determina as ações humanas é a necessidade. Por essa razão a cultura quando compreendida como conjunto das formas da subjetividade social não tem como ser estática, visto que os grupos sociais se adaptam e modificam constantemente, de acordo com as circunstâncias e momento que estão inseridos. 
A relação entre direito e arte, pode não se limitar a meras manifestações artísticas e tornar essa relação eficaz, ao inserir todos os elementos necessários para que essa relação tenha efetividade jurídica e transformá-la em um ponto de partida para o cumprimento da legislação vigente ou, quando esta não for suficiente, para elaboração de propostas legislativas que possam tornar eficazes os direitos decorrentes do Direito à Cidade.

Deve ser constituída uma nova realidade jurídica que contribua para formar um novo perfil da propriedade pública e privada. Novos elementos contando com o microssistema do estatuto da Cidade.

Acompanhando a história das manifestações artísticas com caráter social, notamos diversos marcos essenciais para que possa ser entendida essa história.

O Teatro político deveria recuperar a característica, que tinham conquistado na Antiguidade, para que sua função social seja inteiramente cumprida, e vir a acontecer nas principais cenas da vida pública, ao invés de acontecer majoritariamente nas salas fechadas.

Podemos analisar as circunstâncias dessa forma de teatro a partir do seu conteúdo histórico, reconhecendo a legitimidade da Arte para propor uma gestão participativa, de grande eficácia social, em que os envolvidos nos problemas tenham interesse e participação na luta por soluções a partir desse estímulo cultural. No teatro o seu caráter político passa a também representar a estética do Oprimido.

O cinema deve conquistar, especialmente quando possui caráter jurídico, uma forma de fiscalização do conteúdo mantendo-o de acordo com a norma vigente, e tendo possíveis exibições abertas gratuitas em salas públicas e espaços que possibilitem a projeção e exibição para conscientização de grupos específicos. 
A arte urbana não deve ser apagada, visto que representa uma luta de classes e efeitos altamente nocivos para o bem tombado, como a degradação e o abandono. Os direitos identificados por grupos sociais e então expressados através da Arte são caminhos para que de fato sejam exercidos e se tornem eficazes.

A perda dessa manifestação artística, que se faz presente ao longo dos últimos 15 anos, no caso-referencia do Jockey Clube adotado, como canal cultural de resposta imediata, significaria um claro retrocesso a uma conquista que já faz parte do cenário cultural carioca.

Além disso, espaços que possam vir a reunir essas formas de arte e outras, embora não tenham sido estudados neste trabalho, como a música e a literatura que tanto ensina, por exemplo, além das mais variadas formas de manifestações artísticas, podem se tornar grandes educadores e criar uma consciência coletiva sobre o conhecimento do Direito.

O estudo alcançou como resultado primordial novas possibilidades no processo de interpretação das normas urbanísticas e a melhor compreensão dos conflitos urbanos. Permitiu também a conscientização de direitos, o reconhecimento de demandas coletivas, a articulação dos sistemas através do diálogo de fontes e a abordagem urbana, levando em consideração a constante atualização da mesma no desenvolvimento de pesquisa coletiva.

Consideramos que a pesquisa demonstrou o importante papel da Arte no processo de conscientização para o efetivo exercício dos direitos sociais que constituem o direito à cidade. 


\section{Bibliografia}

ANDREW, J. Dudley. As principais teorias do Cinema. Uma Introdução. $1^{\mathrm{a}}$ ed. Rio de Janeiro: Zahar, Jorge, 1989.

BOAL, Augusto. Teatro do oprimido e outras poéticas políticas. 12 ed. Rio de Janeiro: Civilização brasileira, 2012.

Arte, Cultura e Política. Org.: Zeca Ligiéro, Licko Turle e Clara de Andrade. 1 ed. Rio de Janeiro: Mauad X, 2013.

BERTHOLD, Margot. História Mundial do Teatro. São Paulo: Perspectiva, 2010 .

CASTRO, Sonia Rabello de. O Estado na preservação de bens culturais: o tombamento. Rio de Janeiro: Renovar, 1991.

CAVALLAZZI, Rosângela Lunardelli. Perspectivas contemporâneas do patrimônio cultural: paisagem e urbana tombamento. In Revisitando o instituto do tombamento. FERNANDES, Edésio e ALFONSIN, Betânia (Orgs.). Belo Horizonte: Forum, 2010.

CAVALLAZI, Rosângela Lunardelli \& AYRES, Madalena. Construções Normativas e Códigos da Cidade na Zona Portuária. Rio de Janeiro: Prourb, 2012. 
CAVALLAZZI, Rosângela Lunardelli. O Plano da Plasticidade na Teoria Contratual. Rio de Janeiro, 1993. Tese (Doutoramento) - Universidade Federal do Rio de Janeiro, Rio de Janeiro. 1993.

COMPARATO, Fábio Konder. Fundamento dos Direitos Humanos. In: BOITEUX, Elza Antonia Pereira Cunha (Coord.). Direitos Humanos: Estudos em Homenagem ao Professor Fábio Konder Comparato. Bahia: Podivm, 2010.

COSGROVE, Denis E. Social Formation and Symbolic Landscape. Wisconsin: Wisconsin Press, 1998.

COSTA, Flávia Cesarino. História do cinema mundial. In: MASCARELLO, Fernando (org.). Primeiro cinema. 4 ed. Campinas, SP: Papirus, 2006.

FERNANDES, Edésio \& ALFONSIN, Betânia. Revisitando o Instituto do tombamento. Belo Horizonte: Fórum, 2010.

GASPARINI, Diógenes. Direito administrativo. 3. ed. São Paulo: Saraiva,1993.

GORDILlO, Agustín. Tratado de Derecho Administrativo. 5.ed. Buenos Aires: Fundación de Derecho Administrativo, 2000.

GUIMARÃES, Nathalia. O Tombamento de Bens Imóveis - Apontamentos sobre o Sentido e os Valores do Tombamento de Bens Imóveis na Atualidade e a Proteção do Entorno via Legislação Especial e Urbanística. Uma abordagem Comparada da Legislação Brasileira e da Portuguesa. FERNANDES, Edésio e ALFONSIN, Betânia (Orgs.). Belo Horizonte: Forum, 2010. 
GUINSBURG, J., FARIA, João Roberto \& LIMA Mariangela Alves de. Dicionário do teatro brasileiro: temas, formas e conceitos. 2 ed. rev. e ampl. São Paulo: Perspectiva, 2009.

HÄBERLE, Peter. Teoría de la Constitución como Ciencia de la Cultura. Madrid: Tecnos, 2000 (tradução da segunda edição original, 1996).

HAUSER, Arnold. História Social da Arte e da Literatura. São Paulo: Martins Fontes, 1998.

KONDER, Leandro. Os marxistas e a arte urbana: breve estudo históricocrítico de algumas tendências da estética marxista. 2 ed. São Paulo: Expressão Popular, 2013.

MARX, Karl. O Capital. São Paulo: Nova Cultural, 1985.

Elementos fundamentales para la critica de la economia politica (Grundrisse). México: siglo XXI. 1986.

MELLO FILHO, José Celso de. Constituição Federal Anotada. 2 ed. amp. São Paulo: Saraiva, 1986.

NAGIB, Lúcia. O cinema da retomada. Depoimentos de 90 cineastas dos anos 90. $1^{\text {a }}$ ed. São Paulo: 34, Editora, 2002.

PEREIRA, Lima. Fui crime...serei poesia. Rio de Janeiro: Contrabando Poético, 2014. 
PIRES, Maria Coeli Simões. Da proteção ao patrimônio cultural: o tombamento como principal instituto. Belo Horizonte: Del Rey, 1994.

PORTO, Marta. Por uma Política Pública de Cultura: Desenvolvimento e Democracia. In: SCHOLZE, Lia. Reunião Pública Mundial de Cultura. Porto Alegre: Unidade Editorial, 2003, p. 37

REALE, Miguel. Paradigmas da Cultura Contemporânea, $1^{\mathrm{a}}$ ed., São Paulo: Editora Saraiva, 1996.

REZENDE, Vera F. Resolução no 995. Seminário Plano Diretor, promovido pela Câmara Municipal do Rio de Janeiro, em abril de 2005.

SANTOS, Milton. A Natureza do Espaço: técnica e tempo, razão e emoção. São Paulo: EDUSP, 2002.

SANTOS, Milton. A Natureza do Espaço. - 4. ed. 2. reimpr. - São Paulo: Editora da Universidade de São Paulo, 2006.

SANTOS, Milton. Por uma outra globalização - do pensamento único à consciência universal. Rio de Janeiro: Record, 2013.

SANTOS, Milton. Por uma Economia Política da Cidade. 2. Ed - São Paulo: Editora da Universidade de São Paulo, 2009

SILVA, José Afonso da. Ordenação constitucional da cultura. São Paulo: Malheiros, 2001.

SILVA, José Afonso da. Direito Constitucional Positivo, Malheiros Ed.,

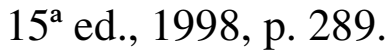


TELLES, Antonio A. Queiroz. Tombamento e seu Regime Jurídico. São Paulo: Editora Revista dos Tribunais, 1992.

. Urbanismo e direito: notas para uma abordagem interdisciplinar do espaço urbano. In: MACHADO, Denise Pinheiro (Org.). Seminário de História da Cidade e do Urbanismo, IV, Rio de Janeiro, 1996. Anais... UFRJ/Prourb, 1996. V. 2, p. 882-887.

O estatuto epistemológico do Direito Urbanístico Brasileiro: possibilidades e obstáculos na tutela do Direito à Cidade. In: COUTINHO, R.; BONIZZATO, L. (Org.). Direito da cidade: novas concepções sobre as relações jurídicas no espaço social urbano. Rio de Janeiro: Lúmen Júris, 2007. p. 53- 69.

Novas Fronteiras do Direito Urbanístico. In: TEPEDINO, Gustavo; FACHIN, Luiz Edson (Org.). O Direito e o Tempo - Utopias Jurídicas e Embates Contemporâneos. Estudos em homenagem ao Professor RicardoCésar Pereira Lira. Rio de Janeiro: Renovar, 2008. p. 683-709.

Direito à Cidade em Projeto. In: MACHADO, Denise Pinheiro (Org.). Tipologias e Projetos Urbanos na Cidade Contemporânea. Porto Alegre: Marcavisual, 2009. p. 41-48.

Relatório parcial de pesquisa do projeto FAPERJ "Códigos da cidade: Análise das interferências jurídico-urbanísticas na cidade standard". Rio de Janeiro: PROURB/UFRJ, 2012.

\section{Filmes:}

"Utopia e Barbárie", de Silvio Tendler 1:48:45 a 1:49:16. $<$ https://www.youtube.com/watch?v=cn9li_NePro $>$.

VAUGHN, Valeri. Art of Conflict. 2012. EUA. 
WAINER, João. Pixo. 2010. São Paulo.

Torre De David - A Vida na Maior Favela Vertical do Mundo. 2013. Venezuela.

\section{Sites:}

$<\quad$ http://direitoeurbanismo.wordpress.com/2013/05/11/paisagem-cariocabaixada-de-jacarepagua-em-transformacao> Acesso em: 03/09/2014.

$<$ http://www.arte.seed.pr.gov.br/modules/conteudo/conteudo.php?conteudo $=179$ > Acesso em: 10/09/2014.

< http://portal.iphan.gov.br> Acesso em: 19/08/2014

http://www.jb.com.br/cultura/noticias/2014/11/02/mostra-africa-hojecomeca-terca-e-vai-ate-o-dia-12-no-ims/ Acesso em: 02/11/2014

RODOTÀ, Stefano. Palestra Professor Stefano Rodotà. Rio de Janeiro, 11 mar. 2003. Disponível em: $<$ http://www.rio.rj.gov.br/dlstatic/10112/151613/DLFE4314.pdf/GlobalizacaoeoDireito.pdf>. Acesso em: 4 ago. 2014. 